\title{
THE HABITATION LAYER OF THE LATE HALLSTATT PERIOD AT THE TRINCA «IZVORUL LUI LUCA» SITE (Northern Moldavian Plateau Area)
}

The Trinca "Izvorul lui Luca" site is an archaeological object with several cultural and chronological horizons, including the late Hallstatt period. The settlement of this period is attributed to the Western Podolian / Podolian-Moldavian cultural group and is the only one investigated in the Northern Moldavian Plateau. The investigations have revealed a number of complexes (dwellings, auxiliary structures, platforms, hearths, and pits), artifacts made of various raw materials (clay, sand, stone, bone, and metal - bronze and iron), a considerable amount of other archaeological remains (pottery, osteological material, stones, fragments of fired clay, etc.) The detailed and overall analysis of all elements specific to the material culture gives us novel information about the way of living, the architectonics of the dwellings, and so on. All this plays a very important role in the research of the cultural and historical processes of the late Hallstatt period in the East Carpathian region in general and in the Northern Moldavian Plateau in particular. The results undoubtedly confirm once again that this region was a zone of cultural interference between the late Hallstatt communities (Thracian) in the Carpathian-Dniester area and the communities in the forest-steppe on the right bank of the Dnieper that existed simultaneously with them.

Keywords: settlement, Trinca "Izvorul lui Luca", Northern Moldavian Plateau, the Western Podolian / Podolian-Moldavian cultural group, the early Scythian period, Thracians, Scythians.

\section{GEOGRAPHIC FRAMEWORK}

The Trinca locality is in the north-western part of the Republic of Moldova, in the area of the left bank of the Prut River (fig. 1), the physico-geographical region of the Northern Moldavian Plateau (Рымбу 1982, с. 94-99). Newly, it became also called the region of the Northern Moldavian Plateaux and Plains (Boboc, Sârodoev 2010, p. 14).

(c) O. LEVIȚKI, L. SÎRBU, G. SÎRBU, 2019
The relief of the Northern Moldavian Plateau is characterized by a clear asymmetry, being inclined to the southwest (the highest altitudes in the north-east are $300-305 \mathrm{~m}$ and in the south $250 \mathrm{~m}$ ). It is a hilly and fragmented plain, at the base of which there is the Moldavian Platform. The relief is formed mainly in sediments of Neogenic age (clay, sand, limestone, marl) and only occasionally in older Meso-Paleozoic rocks (sandstone, clayey shale, marl, limestone). Most of the territory is fragmented by a network of valleys of small rivers, approximately parallel, the depth of which is $60-100 \mathrm{~m}$, and the interfluves are flat and relatively wide.

In the context of this work, we believe it useful to consider the natural and geological-paleontological specificity of the western part of the Northern Moldavian Plateau, in which the Trinca commune is located, respectively the site of Trinca «Izvorul lui Luca» with several cultural-chronological horizons.

The peculiarity of the western part of the Northern Moldavian Plateau is the strip of reefs / toltras. Toltras are Neogene reef formations, they are spread in the north-western part of the Republic of Moldova on an area of about $2500 \mathrm{~km}^{2}$ (for a length of over $100 \mathrm{~km}$ along the Prut River - from Larga to Bolotina and the width of about $50 \mathrm{~km}$ - the most eastern point in Bârladeni, in the Ciugur River valley). They are located in stripes from the northeast to the southwest, like the valleys of the left tributaries of the Prut River - Larga, Vilia, Lopatnic, Draghişte, Racovăt, Ciugur, Camenca, Căldăruşa (Сухов 1972, с. 13-14, карта; Янакевич 1973, с. 20-31; Кравчук, Верина, Сухов 1976, с. 76, 85; Рымбу 1980, с. 23-25). Toltras were formed of organogenic limestone consisting of algae, cor- 
als, bryozoa, sponges, mollusk shells, and so on. Over the course of millions of years the strip of reefs has outcropped. Thus, in the modern relief, these geological formations appear as massive reefs in the form of domes, with a height of up to $80-100 \mathrm{~m}$. The tributaries of the Prut River at the intersection with the reef strip form limestone valleys with steep banks and deep gorges.

Forms of relief, favorable climatic conditions, richness and diversity of fauna and flora have determined the relatively early population of the area between the Dniester and the Prut. Prehistoric people began to live in this area in the middle phases of the early Paleolithic. The sites in the Northern Moldavian Plateau show an intense continuation of human life in this region, including during the late Hallstatt period, antiquity, etc. (see Istoria Moldovei 2010, Hărțile... p. 109, 129, 235, 251, 269, 282, 290, 297, 304, 334, 423, 529 , etc). This area was more or less populated by both settled farmers and livestock communities, as evidenced by the habitation layers in the settlement of Trinca "Izvorul lui Luca».

With the appearance in the Eastern Carpathian territories of the Thracian tribes who inhabited the entire forest-steppe zone up to the late Hallstatt period, the Northern Moldavian Plateau became an area of cultural interference between the Thracian communities and the neighboring communities in the East, of the BelogrudovkaCernyj Les type - Early Scythian. The material and spiritual culture characteristic of this era is of a mixed character, as evidenced by the remains of the Trinca "Izvorul lui Luca» multi-layered settlement and by some burial complexes (Levițchi 1992 , p. 119-121). The share of the native, Thracian and alien elements of traditions in the territory north and northeast of the Dniester attested in the funeral rite and ritual practiced by the communities that inhabited the area of Northern Moldavian Plateau during the late Hallstatt period are widely presented in the necropolis of Trinca «Drumul feteştilor» (Levițchi 2006).

\section{THE LOCATION OF THE SITE AND THE DEVELOPMENT OF ITS RESEARCH}

The Trinca «Izvorul lui Luca» archaeological site is located about $2.5 \mathrm{~km}$ south of the southwestern outskirts of the village of Trinca, Edinet District. It occupies almost the whole area of a promontory formed by a bend of the Draghişte River, on its right bank. The promontory is longitudinally oriented from the northwest to the southeast; its highest altitude is $213.3 \mathrm{~m}$ at the north end and $183.3 \mathrm{~m}$ at the south-east, thus having the surface inclined to the southeast by $2.7^{\circ}$. The height of the promontory from the level of the Draghişte river bed is about $30-40 \mathrm{~m}$. From the northwest, the promontory is protected by a massive limestone plateau, with an altitude of $248.1 \mathrm{~m}$. In general, the place of the settlement is protected by the opposite bank, high $(238.3 \mathrm{~m})$, rocky and wooded (fig. 1: III).

The archaeological object Trinca «Izvorul lui Luca» was discovered in 1981 by archaeologist I. Borziac. At the time of discovery, the territory of the site was cultivated annually. On the surface, there were visible gray oval shaped spots, which were agglomerations composed of stones, fragments of pottery, animal bones, flint splinters, daub, and so on. Outside the spots, archaeological remains were rare or missing. The dimensions of the spots are $16 \times 18 \mathrm{~m}$. The distance between them ranges between $20-25 \mathrm{~m}$ and they were placed in the following way: 5 along the northeast extremity of the promontory; 4 - along the southwest extremity; three of them were disposed at an angle of 45 degrees from the southwestern extremity to the northeast, and there was a spot in the center of the promontory (Левицкий 1986, c. 55). The pottery and some objects collected from the surface of the spots allowed us to attribute the settlement predominantly to the first stage of the Iron Age.

The excavations were started in 1982 by O. Leviți and continued, as much as possible, in 1984,1989 , and 1990 . It is noteworthy that in 1989 , based on the scientific collaboration program between the Academy of Sciences of Moldova and the Academy of Sciences of Ukraine, the area of the settlement was explored by the magnetometric cartography method (determination of the soil resistivity) which resulted in the discovery of some visually undetectable complexes. In order to confirm that along with the complexes represented by the agglomerations of remains of material culture there are other habitat structures in the limits of the settlement, two other excavations (SIV and SV) were carried out in 1989 and 1990, in which surface dwellings, pits, other arrangements have been discovered, as well as several utensils, tools, and a significant amount of mass archaeological material that indicate the existence of the late Hallstatt cultural-chronological horizon.

\section{THE HABITATION LAYER OF THE LATE HALLSTATT PERIOD}

The remains of the late Hallstatt period in the Trinca "Izvorul lui Luca» settlement are located mainly in the south-east of the site, now treeless on the promontory. The complexes that are clearly attributed to this horizon, that is, surface dwellings, auxiliary constructions, pits and other agglomerations of materials are concentrated mainly in the indicated zone and occupy a limited area at the extremity of this. In the excavations made in this area of the promontory (nos. IV, V), the vast majority of the archaeological material, mostly concentrated around the mentioned complexes, was found. Besides, in the other excava- 

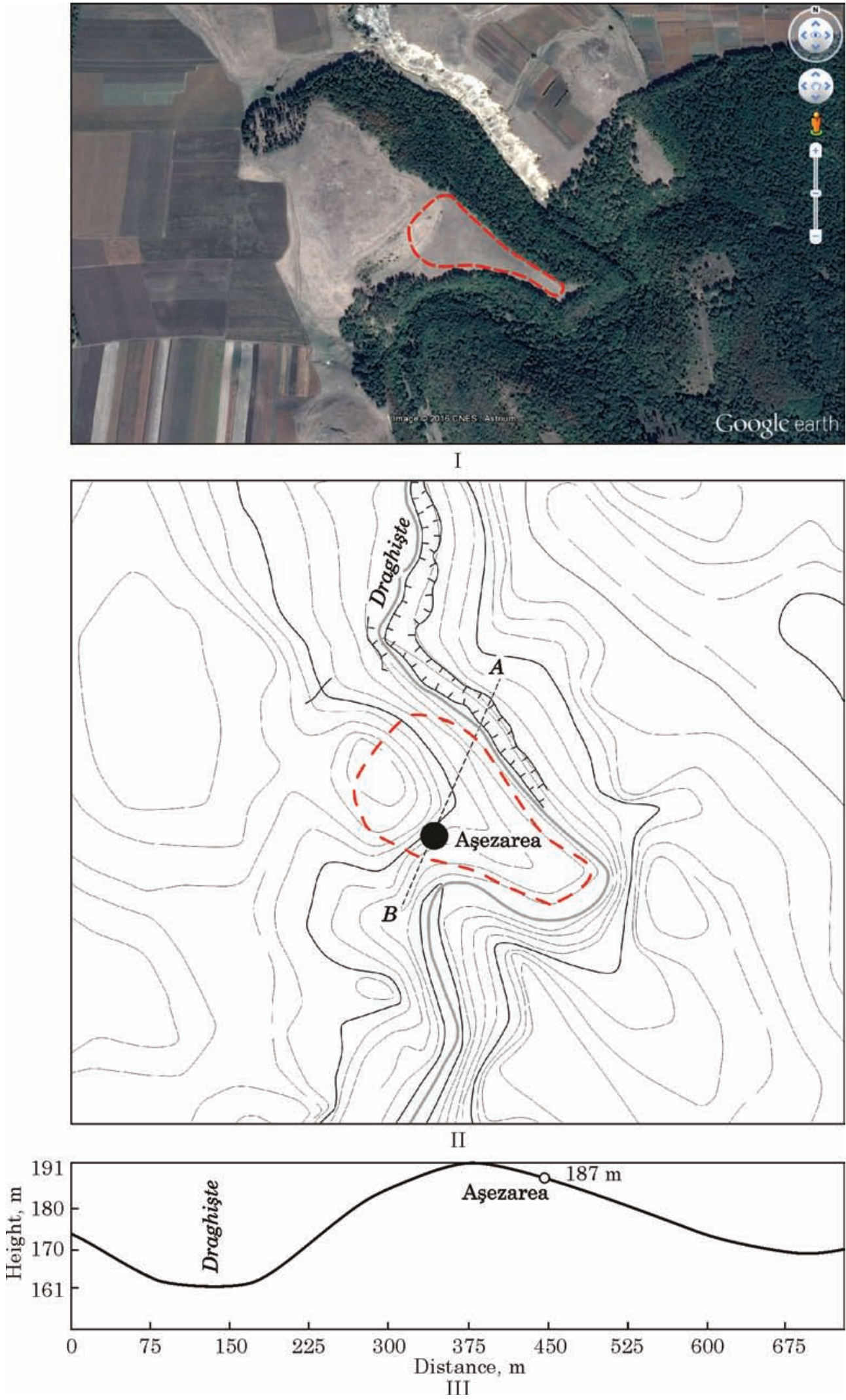

Fig. 1. Trinca «Izvorul lui Luca»: I - orthofothomap; II - topographic sketch; III - elevation profil

tions, remains of the late Hallstatt period, with rare exceptions, are virtually missing. At the same time, small-scale excavations carried out on the flat area of the promontory, directly ad- jacent from the east to the zone of the location of the complexes of the late Hallstatt period, have shown that the southeast extremity of the promontory, now covered with the forests, was also in- 
habited in ancient times, and, it is not excluded, by the community that seized the promontory in the period under consideration.

\section{HABITAT COMPLEXES, ANNEXES, PITS}

Within the investigated area of the Trinca «Izvorul lui Luca" settlement, in the habitation layer of the late Hallstatt period there were discovered the remains of three surface dwellings, a ring of limestone that surrounds a large pit, and several pits.

Dwelling 1 (IV/1989) (fig. 2: A) was found at a depth of about $0.45-0.55 \mathrm{~m}$ from the modern ground surface. It is a surface dwelling of quasiquadrangle shape (the sides of about $4.0 \times 4.5 \mathrm{~m}$ ), oriented on the east-west axis. The remains of the construction consist of a compact agglomeration of adobe, pieces of daub, and broken limestone

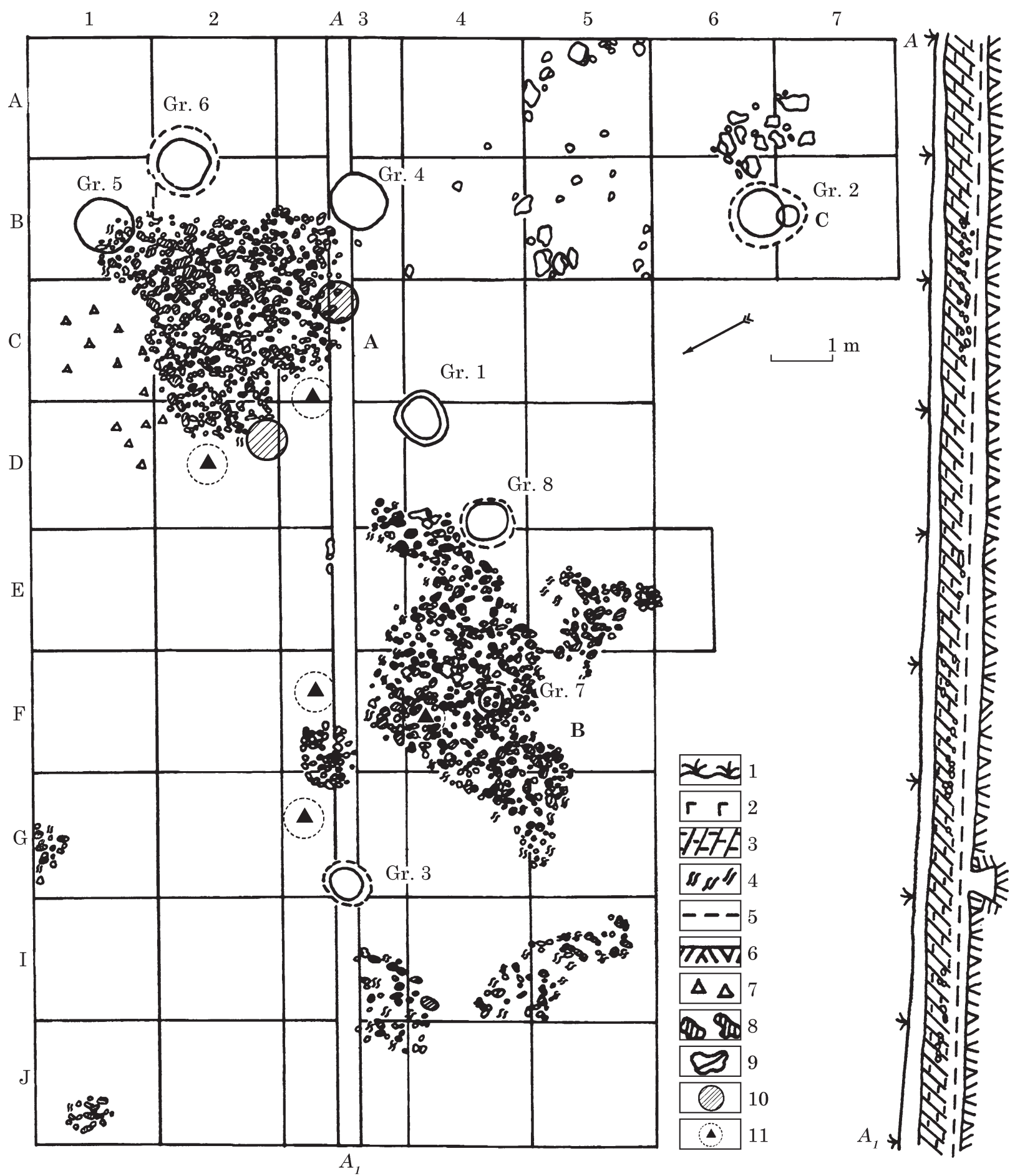

Fig. 2. Trinca Trinca «Izvorul lui Luca», Excavation IV: 1 - current horizon level; 2 - vegetal layer; 3 - ash layer; 4 - black-grayish layer; 5 - grayish-yellowish soil; 6 - bright yellow clay; 7 - fragments of pottery; 8 - adobe, daub; 9 - stones; 10 - restorable vessel-wheel; 11 - fragmented vessel-wheel 


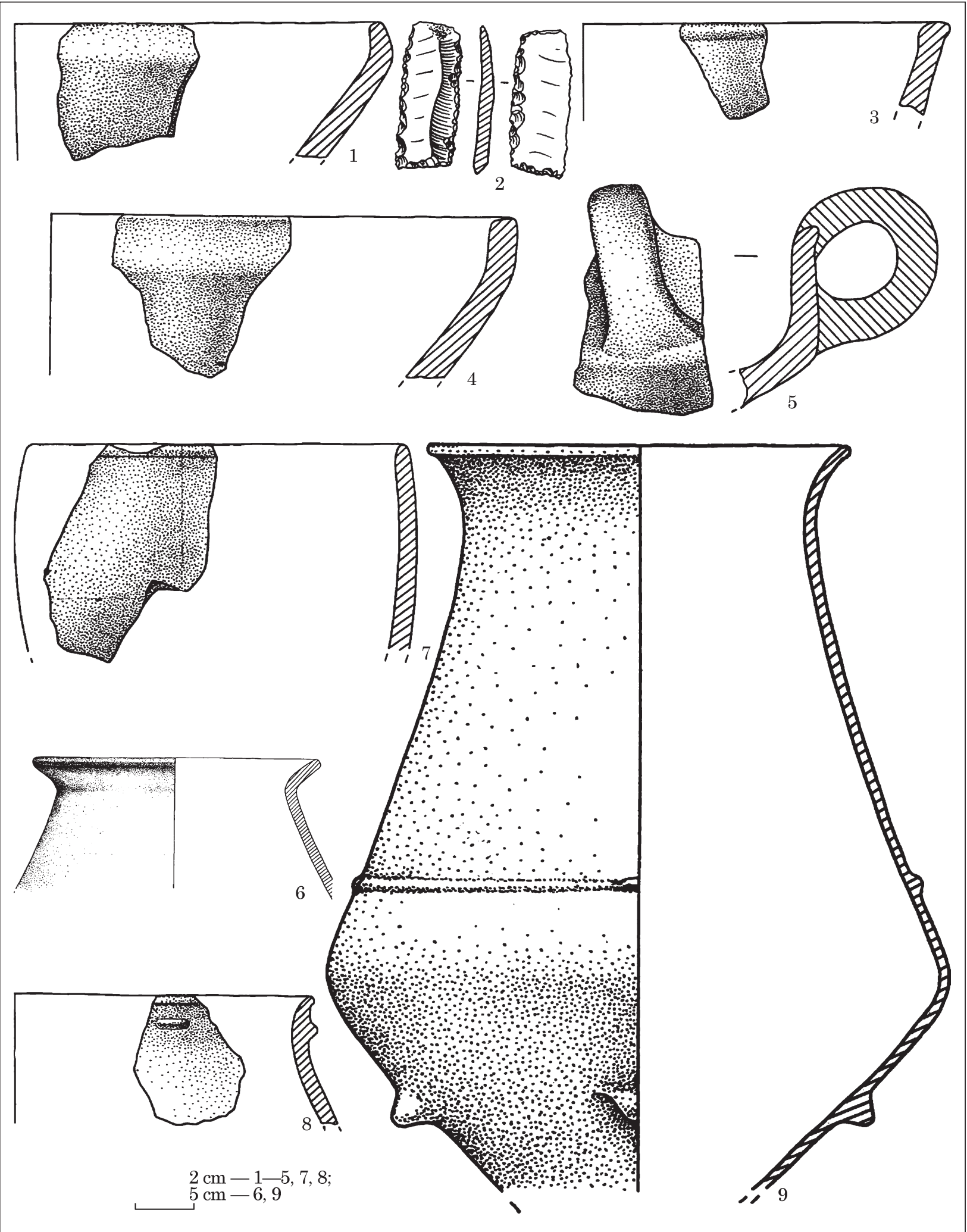

Fig. 3. Trinca «Izvorul lui Luca», Hand-shaped pottery, flint blade for sickles — Excavation IV: 1, 3—9 — burned clay; 2 - flint

stones about $0.1 \mathrm{~m}$ thick, as well as remnants of material culture. Directly near the eastern side there are 2 pits (nos. 5 and 6), the first one is partly covered by the remains of the dwelling. Another pit (no. 4) is located near its southern side. In the area occupied by remains of the construction, in the filling of pits 5 and 6 , and in adjacent squares there were collected fragments of pottery, animal bones, and flintstones, some of which were burnt.

The collection of pottery found within the remains of the dwelling and directly near it, with 


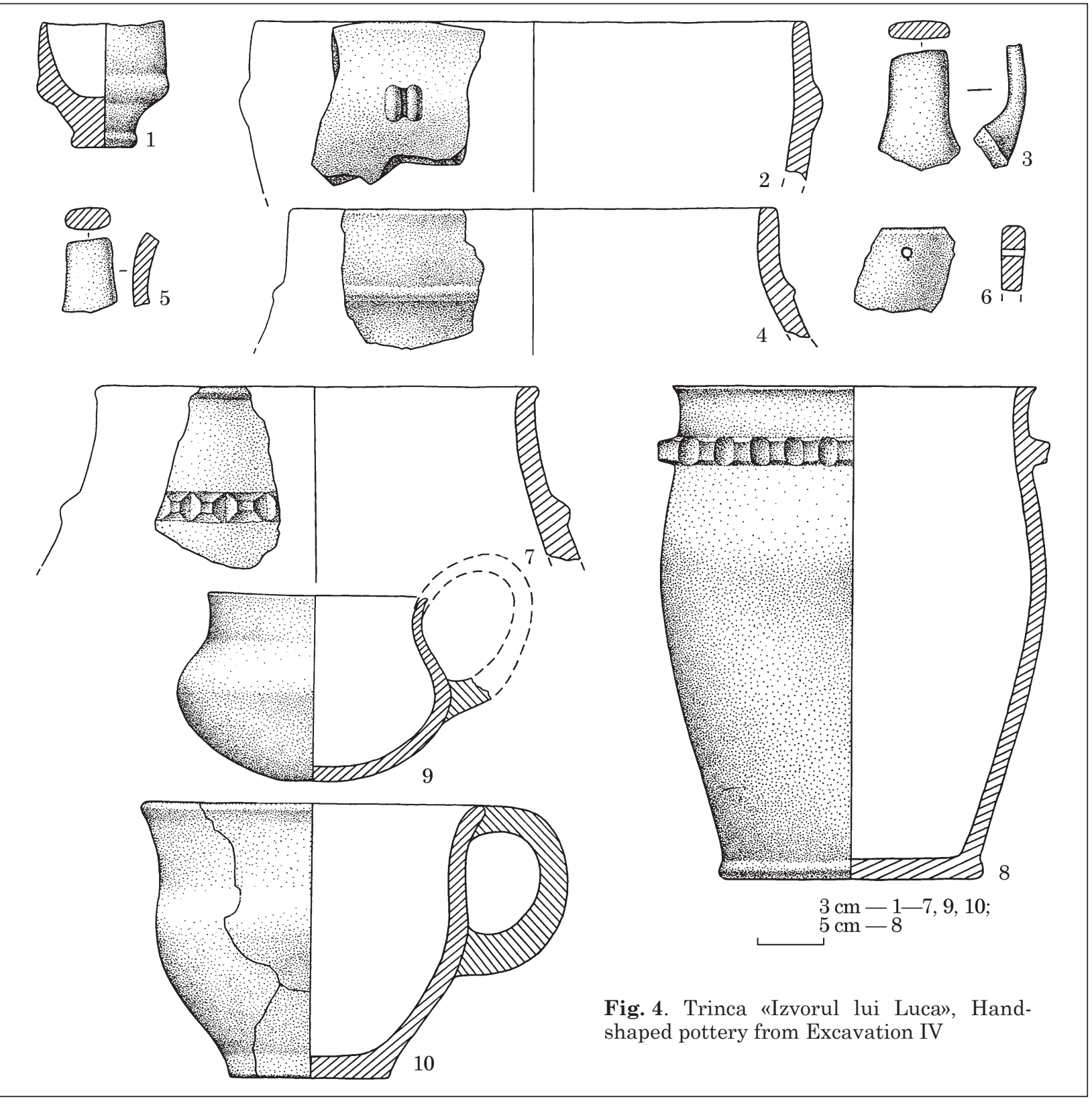

the exception of 3 fragments of fine pottery of the Horodiştea-Gordineşti type, consists of vessels and fragments of vessels of the late Hallstatt period, among which there are two technological categories: hand-shaped pottery and wheelmade pottery. The percentage ratio between these categories is $88.7 \%$ (220 fragments) and $11.3 \%$ (28 fragments).

The hand-shaped pottery shows the presence of two conditional categories: fine ware and common ware, the percentage ratio of which is $57.4 \%$ (128 fragments) and $11.3 \%$ (95 fragments) respectively. Among the fine ware there are large amphora-shaped containers with a double truncated cone shaped body, the funnel-shaped neck, the rim arched outward, and a relatively narrow bottom, which are provided in the widest part of the body with relief ribbon interrupted by four horizontal oval symmetrically placed projections, and below have four symmetrical knobs (fig. 3: 9) and the upper part of another large vessel with the funnel-shaped neck and the rim sharply bent outward (fig. 3: 6), wide truncated cone bowls with thinned edges curved inward (fig. 3: 1), and mugs with raised handles (fig. 4: 3, 5). Among the common wares there are tulip-shaped vessels, jar-shaped vessels or pots ornamented with a row of perforations below the rim (fig. 4: 6) or with simple or alveolated horizontal belts on the shoulder (fig. 4: 4, 7).

The wheel-made pottery are mostly gray with the burnished surface and are represented by Kruglik-type vessels with the thickened, flared and horizontally cut edge (fig. 5: 1), the short neck undelimited from the rounded body, and the flat bottom (fig. 5: 9), which have a narrow rib at the junction of the neck with the body (fig. 5: 6), and by the relatively thin-walled vessels - mugs / cups and possibly jugs (fig. 5: 2, 3). 


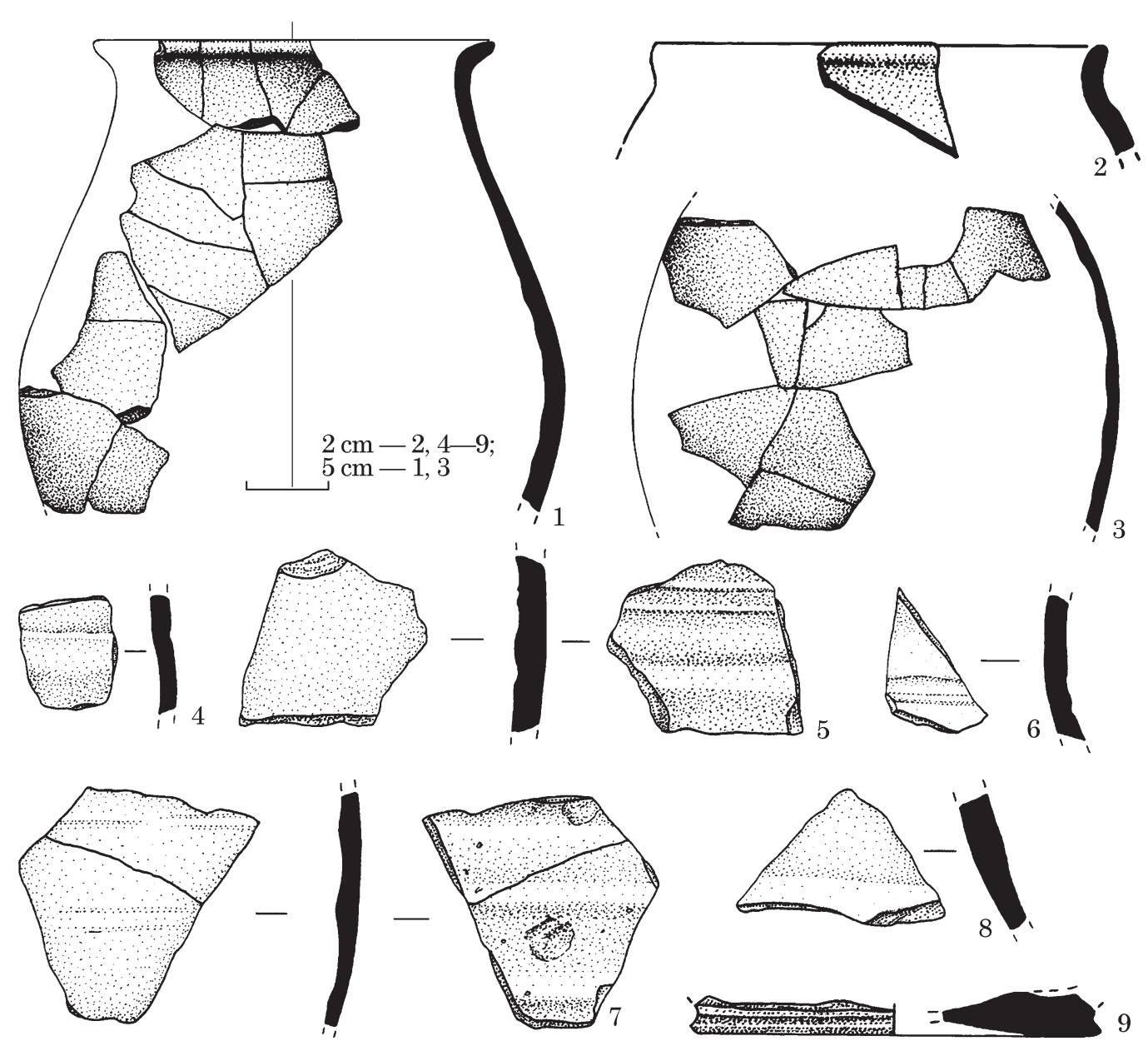

Fig. 5. Trinca «Izvorul lui Luca», Wheel-made pottery from Excavation IV

Dwelling 2 (IV/1989) (fig. 2: B) was found at the same depth of $0.45-0.55 \mathrm{~m}$ from the modern ground surface. The remains of the construction consist of several platforms and agglomerations of adobe, pieces of daub, limestone stones - about 0.1 to $0.15 \mathrm{~m}$ thick, as well as remnants of material culture placed on a quasi-quadrilateral area (about $6.5 \times 8.0 \mathrm{~m}$ ), oriented on the east-west axis. Approximately in the middle of the northern side of the dwelling, outside it, there is an oval shaped stone platforme $(1.1 \times 0.8 \mathrm{~m})$, similarly oriented from the east to the west, consisted of a layer of limestone slabs of medium and small size with a thickness of $0.1-0.18 \mathrm{~m}$, without signs of burning. On the opposite side, in the middle of the southern side, the remains of an open hearth located on an area of $0.75 \times 0.5 \mathrm{~m}$ were identified, which is represented by pieces of daub 0.08 $0.1 \mathrm{~m}$ thick. The surface of the hearth, carefully finished, has traces of intense burning. In the central part of the dwelling, on the same line as the stone platform and the hearth, under the adobe agglomeration, pit 7 was identified. Two other pits (nos. 3 and 8) are located in the south-east and the north-west corners of the construction. The filling of the pits 7 and 8 , from the level of their detection to the depth of $0.4 \mathrm{~m}$ and $0.3 \mathrm{~m}$ respectively, consists of fragments of adobe, daub, small burned stones. In the area occupied by the remains of the dwelling, including the platform and the hearth, the filling of pit 8 and neighboring squares, fragments of pottery, animal bones, and flintstones were collected, some of which were burned.

The assemblage of pottery found in the dwelling and directly near it, with the exception of 6 fragments of fine pottery of the Horodiştea-Gordineşti type, consists of vessels and fragments of vessels of the late Hallstatt period, which represent two technological categories: the hand-shaped pottery and the wheel-made pottery. The percentage ratio between these categories is $96 \%$ (173 fragments) and $4 \%$ (7 fragments).

The hand-shaped pottery represents two conventional categories: fine ware and common ware, with a percentage ratio of $22.5 \%$ (39 fragments) and $77.5 \%$ (134 fragments). Among the fine ware there are: unornamented mugs - a low specimen with a round body, a short cylindrical neck with a slightly flared edge, a narrow flat bottom and a raised handle (fig. 4: 9), another, wide open, with a slightly S-shaped body, the flat bottom, provid- 
ed with the handle that joins the edge with the shoulder (fig. 4: 10) and one with the short body, with high vertical upper part thinned to the edge and slightly raised handle (fig. 3: 5) and truncated cone bowls with the vertival straight edge (fig. 3: 4) or wide open ones, truncated conic, with a straight rim, the edge of which is rounded and slightly thickened (fig. 3: 3). The common ware is represented by medium-sized tulip-shaped vessels, one with horizontally arranged oval protrusions below the edge (fig. 3: 8) and jar-shaped vessels slightly rounded to the mouth, with thinned edge slightly bent inside (fig. 3: 7) or with the straight vertical edge, with vertically perforated protrusions below the edge (fig. 4: 2), as well as a container with the body slightly widened at the middle (the double truncated cone shape) ornamented below the edge with a massive alveoli belt interrupted by two symmetrically arranged knobs (fig. 4: 8).

The wheel-made pottery, technologically similar to that of the previous dwelling - with gray burnished surface, is represented only by fragments of vessels with relatively thin and thick walls belonging, possibly, to the Kruglik-type containers.

Dwelling 1 (V/1990) (fig. 6) was found at a depth of about $0.40-0.55 \mathrm{~m}$ from the modern ground surface. It is a surface dwelling, of which it was possible to investigate only a half, because the other half is in the wooded area of the promontory. As can be seen from the configuration of the investigated part, the dwelling was quasi-quadrilateral (about $8.0 \times 6.0 \mathrm{~m}$ ), oriented on the southwest-northeast axis. The remains of the construction consist of an agglomeration of pieces of adobe, daub, and limestone stones about $0.1-0.14 \mathrm{~m}$ thick, as well as of the remnants of material culture. From the area occupied by the remains of the dwelling and from the neighboring squares fragments of pottery, animal bones, flintstones, and some other finds were collected. The last ones are two fragments of spindle-whorls made of fired clay (fig. 7: 3,4), three ceramic vessels - a miniature vessel (fig. 7: 6), a mug (fig. 7: 7), and a tulip-shaped vessel (fig. 7: 9), two flint blades for sickles (fig. 7: 2), a sandstone grinder, a bronze needle rod (fig. 7: 8), and a fragment of $a$ pestle made of a river pebble.

Pottery found among the remains of the dwelling and directly near it, with the exception of 29 fragments of the Horodiştea-Gordineşti type (exclusively from the category of fine pottery), belongs to the first stage of the Iron Age. In the Iron Age pottery assemblage, in terms of the modeling technique, there are two technological categories: the hand-shaped pottery and the wheel-made pottery, the percentage ratio of them being $95.2 \%$ (1212 fragments) and $4.79 \%$ (61 fragments).

The hand-shaped pottery is also represented by two conventional categories: fine ware and common ware. The percentage ratio between these categories is $14.94 \%$ (181 fragments) and
$85.05 \%$ (1030 fragments). Among the fine pottery there are amphora-shaped vessels of a double truncated cone shape, with funnel-shaped neck and flared rim, some decorated with conical protrusions (fig. 8: 8, 14); wide open bowls of a truncated cone shape, with the body rounded to the mouth and the flared edge, one specimen is ornamented on the top by roughly executed parallel horizontal grooves (fig. 7: 1, 5; 8: 2, 4-6); mugs of a truncated cone shape with the raised handle (fig. 8: 1,3); and mugs with accented Sshaped body - both without ornament (fig. 7: 7), and unornamented cups with the rounded body, the high neck of truncated cone shape and the narrow bottom with umbo (fig. 7: 10). Among the common ware there are tulip-shaped vessels ornamented by a string of holes arranged below the rim; by oval protrusions arranged obliquely on the shoulder of the vessel, a row of holes under the rim in combination with oval protrusions disposed obliquely on the shoulder of the vessel, oval, alveolar protrusions disposed horizontally on the shoulder of the vessel, a simple belt on the shoulder of the vessel, a row of holes arranged below the edge and a horizontal alveolated belt $8 \mathrm{~cm}$ below, on the neck, from which a similar segment (fig. 7: 9, 11, 12; 8: 11, 12, 15), jar-shaped pots ornamented below the edge with a row of holes or a row of punctures, in combination with an alveolated belt disposed below the edge of the vessel, a mouth diameter of about $31 \mathrm{~cm}$ (fig. 8: 7, 13), and vessels with quasi double truncated cone shaped body, with a row of holes below the edge in association with an alveolated belt placed below it (fig. 8: 9) or only with the alveolated belt below the edge (fig. 8: 9, 10).

The wheel-made pottery, mostly of gray color with burnished surfaces, is represented by a mug with the body of double truncated cone shape and the flared edge, the slightly concave bottom and the raised handle (fig. 9: 1), vessels with high handles with round section (fig. 9: 2), two containers with flared edge with a groove on the outer surface (fig. 9: 4, 5), Kruglik-type vessels (fig. 9: 3, 6-9), and, possibly, bowls with flared edge.

The ring of stones (IV/1989) (fig. 2: C) was found at the depth of the dwellings, about $2 \mathrm{~m}$ south of them. Judging by the outline of the eastern part, it can be presumed that it initially had a circular shape with a diameter of about $5 \mathrm{~m}$ and a height of about $0.2-0.25 \mathrm{~m}$. It is made up of large broken limestone stones $(80 \times 40 \times 20 \mathrm{~cm}-50 \times$ $25 \times 20 \mathrm{~cm})$ deposited in a single layer, among which there are also smaller stones. In the southwest part of the ring, there is an amorphous platform of flat stones and a large pit (no. 2). Among the stones that make up the ring and the platform, as well as in the filling of the pit, fragments of common ware of the Iron Age, animal bones, and flintstones were found.

The pits found near or inside the surface dwellings have an oval or irregular circular shape 


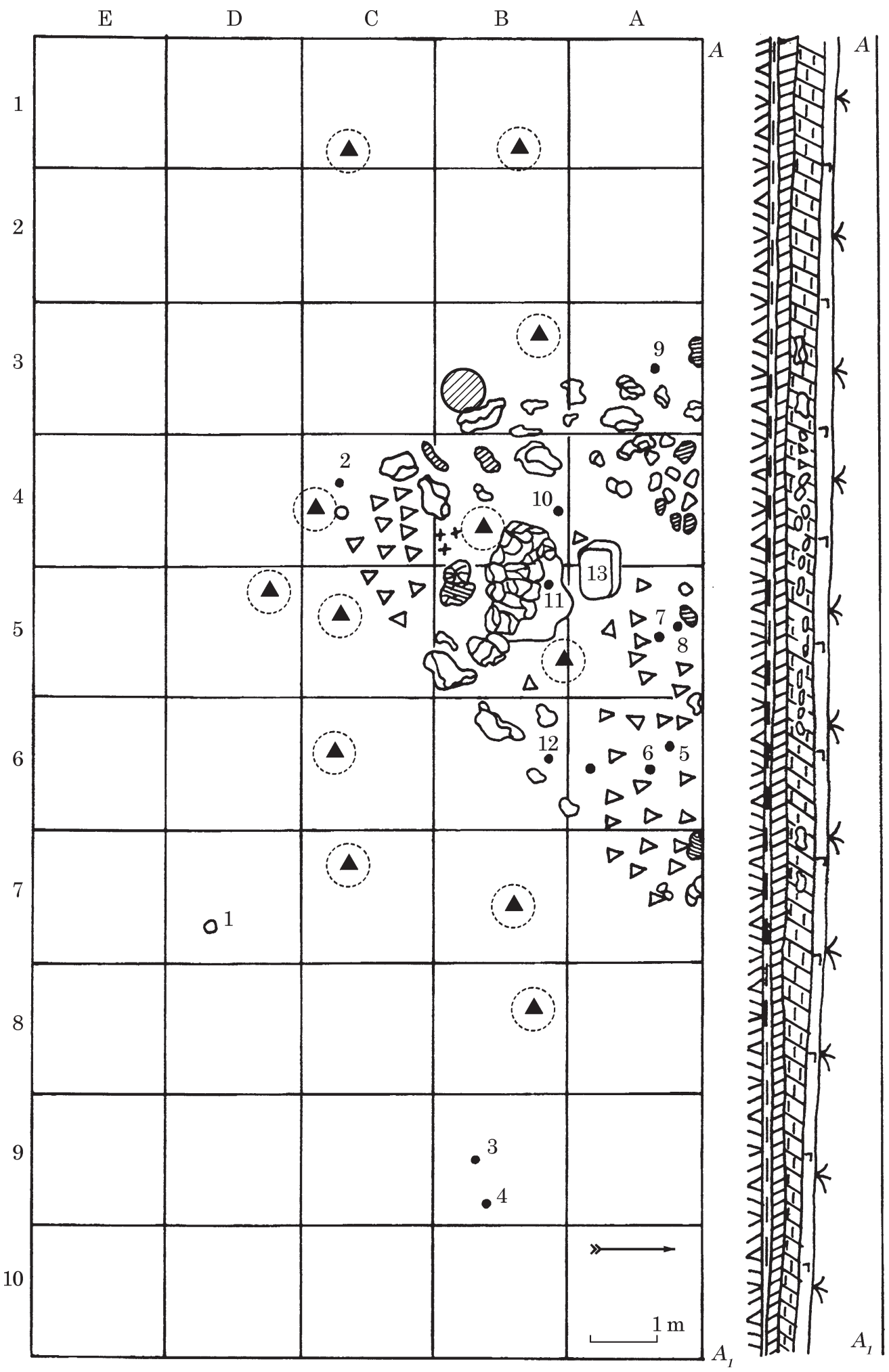

Fig. 6. Trinca «Izvorul lui Luca» - Excavation V. Legend see at fig. 2

in plan, with the horizontal bottom, they differ in size (diameter at the detection level ranging from 0.8 to $1.5 \mathrm{~m}$, bottom diameter from $0.8 \mathrm{~m}$ to $1.3 \mathrm{~m}$, depth from 0.4 to $1 \mathrm{~m}$ ) and in shape of the section: with the walls narrowing to the bottom (pit 1); with vertical walls (pits 4 and 5); with the bellshaped profile (pits nos. 3, 6-8). Pit 2, IV/1989 from the stone ring had an oval shape with diam- eters of $0.68-0.72 \mathrm{~m}$ and the bell-shaped section. Its depth is $0.80 \mathrm{~m}$; the bottom diameter is about $1.28-1.30 \mathrm{~m}$ (fig. 2). In the southwest part of the bottom of the pit there is a recess of oval shape, the walls of which narrow to the bottom with the inclining from the north to the south. Diameters of the recess are $0.5-0.36 \mathrm{~m}$ and the depth is $0.18-0.22 \mathrm{~m}$ (fig. 2). 


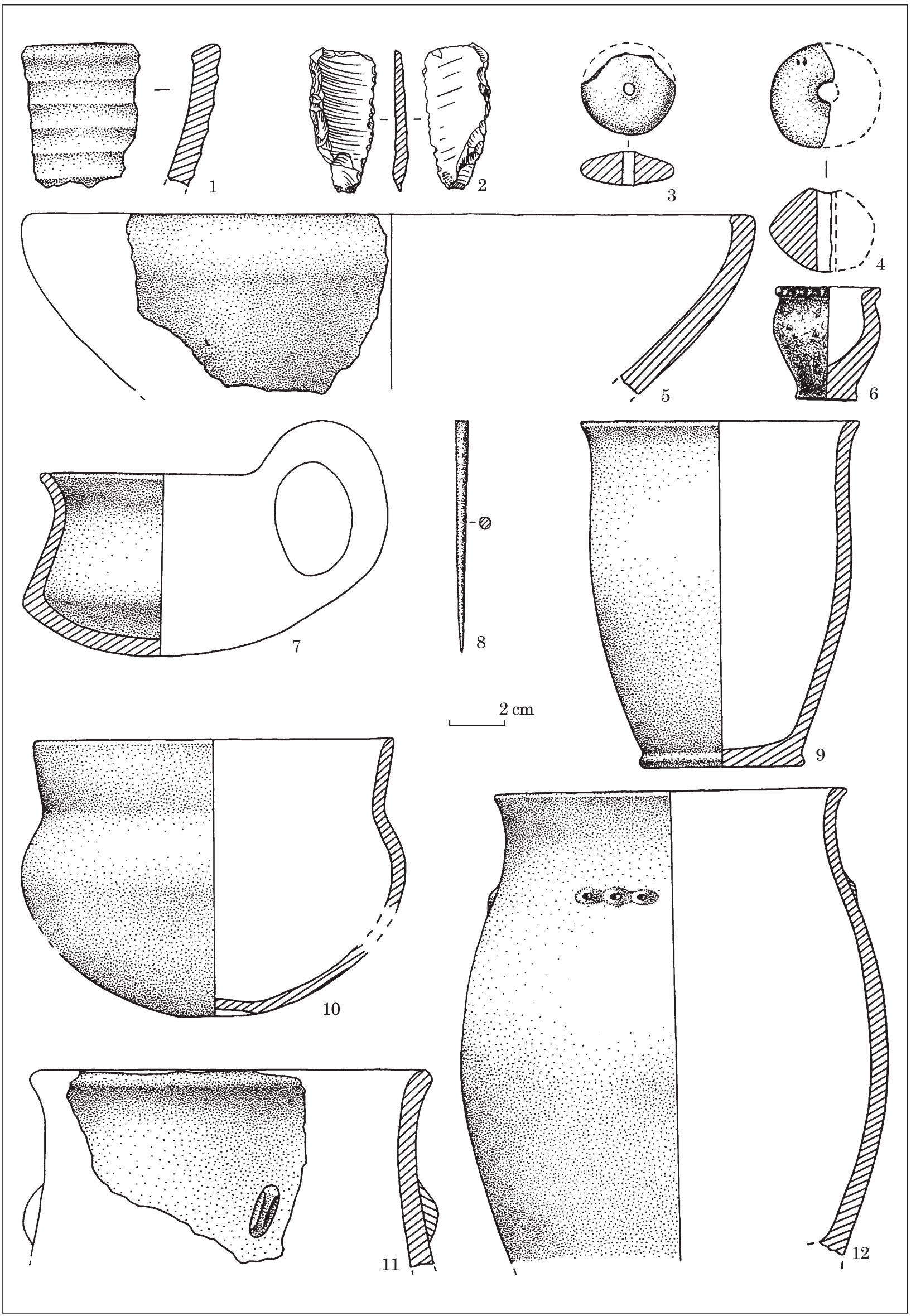

Fig. 7. Trinca «Izvorul lui Luca», Hand-shaped pottery; finds from Excavation V: 1, 3—7, 9—12 — burned clay; 2 - flint; 8 - bronze 


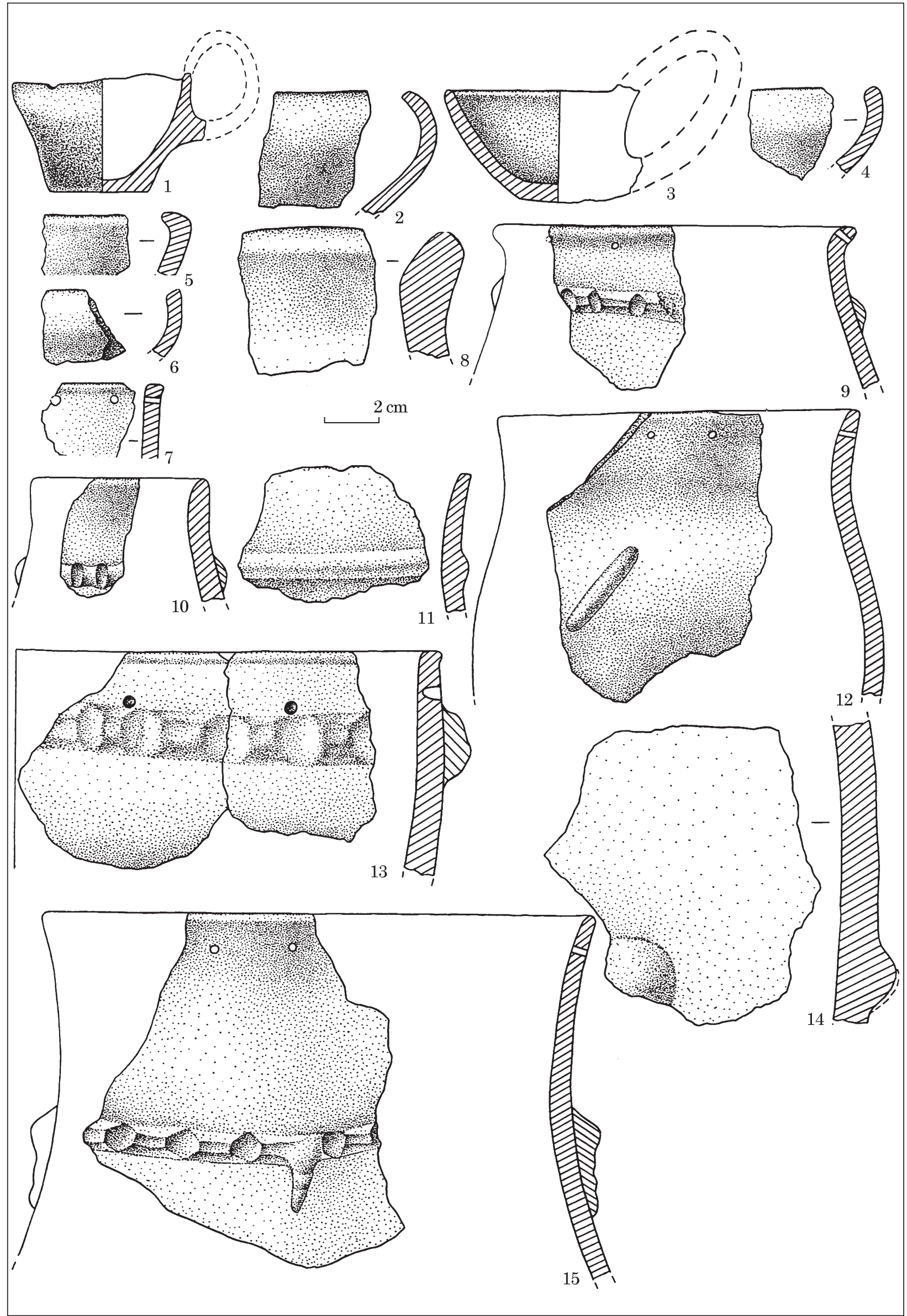

Fig. 8. Trinca «Izvorul lui Luca», Hand-shaped pottery from Excavation V 


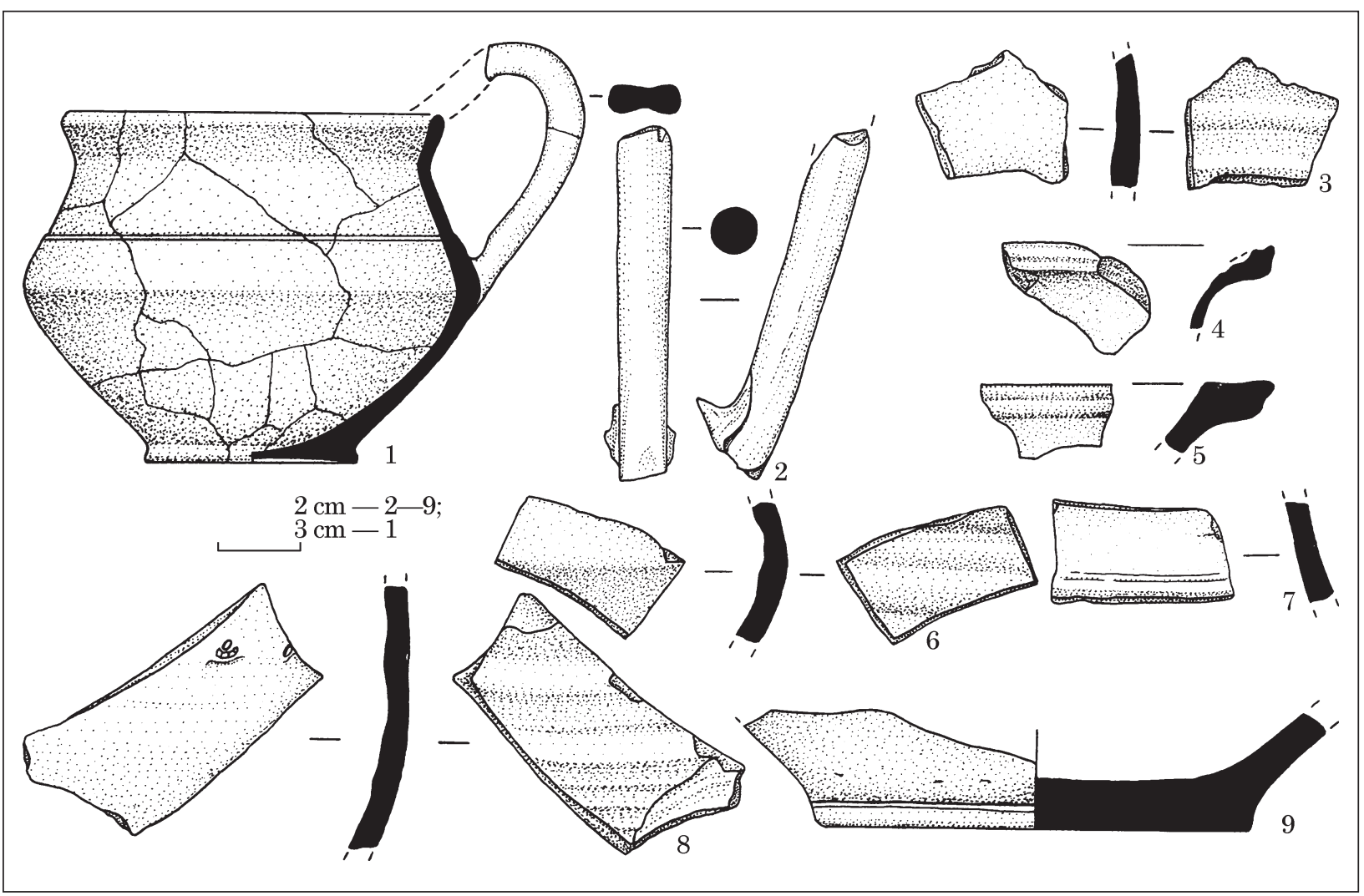

Fig. 9. Trinca «Izvorul lui Luca». Wheel-made pottery from Excavation V

Regarding the destination of the pits in the housing complexes of the late Hallstatt period at Trinca, we can assume that those in the dwellings or directly near them were used in particular as storages or cellars. Certain household functions, initially, probably fulfilled the other pits, and only later they were used to store household waste.

Pottery. According to the modeling technique, there are two categories in the late Hallstatt pottery collection: the hand-shaped pottery and the wheel-made pottery. Based on the collected fragments, the share of wheel-made pottery is $8.88 \%$ in Excavation IV (1989) and $4.8 \%$ in Excavation V (1990).

The hand-shaped pottery. In terms of technology, two main conventional categories are identified: fine ware and common ware. The first category includes pottery made of a compact clay body, well kneaded, having as a degreasing component finely crushed ceramic shards, sometimes in combination with sand, fine grained gravel or mica. The surfaces of the vessels are smooth or burnished, sometimes covered with slip, predominantly gray or brown with darker or lighter spots. The second category includes pottery molded of a coarse clay body mixed with coarsely crushed shards, rarely in combination with small limestone stones and fine grained gravel or with sand and mica. Surfaces of the vessels, generally smoothed, have some unevenness, in some cases voids. The color is gray of various shades or brown with gray spots. The vast majority is common ware, the share of fine ware ranging between $15 \%$ (Excavation V, 1990) and $39.24 \%$ (Excavation IV, 1989).

In terms of technology, morphology and ornamentation, hand-shaped pottery has a homogeneous character. The following types of pottery are identified in the fine ware: amphora-shaped vessels, bowls, mugs and cups, the shares of which are respectively $67,15.6,14,9$, and $2,5 \%$, and in the common ware: tulip-shaped vessels, jar-type pots, and vessels with slightly truncated cone shaped body, the shares of which are respectively $63.5,30.6$, and $5.9 \%$.

\section{The fine ware.}

Large vessels of double truncated conical shape. A distinctive feature of these vessels is two colors: their outer surface, well-treated, is black or dark gray, and the inner one is yellow, orange or light gray. There are the following types:

a) a large vessel with a double truncated cone body, a funnel-shaped neck, an arched outward rim, and a relatively narrow bottom. The upper part of the vessel is twice as large as the lower part and the height exceeds the maximum diameter. Above the most prominent part, the vessel has a relief rib interrupted by four symmetrically placed horizontal oval projections, and below it has four symmetrically placed massive knobs (fig. 3: 9);

b) a large vessel with a double truncated cone body, a funnel-shaped neck, and a sharply flared rim (fig. 3: 6). 
The vessels of double truncated cone shape in the upper part of the body can be ornamented with conical protrusions (fig. 8: 14).

Bowls. Several variants of unornamented vessels are identified:

a) wide open bowls, of truncated cone shape, with the flat bottom, straight walls at the top and the thin rim bent inward (fig. 3: 1) or vertical with strait edge (fig. 3: 4);

b) bowls of truncated cone shape, with a body rounding to the mouth and the edge curved inward and rounded (fig. 8: 2, 4), thinned (fig. 8: 5), horizontally cut (fig. 7: 5) or obliquely cut (fig. 8: 6 ). With the exception of one specimen with the obliquely cut edge, which is ornamented in the upper part with coarsely made parallel horizontal grooves (fig. 7: 1), other vessels have no ornamentation (fig. 7: 5);

c) bowls of truncated cone shape, with straight walls in the upper part and the strait rim, with rounded and slightly thickened edge (fig. 3: 3).

Mugs are represented by several intact unornamented spesimens, which are morphologically subdivided into the following types:

a) low mug with the round body, short cylindrical neck, slightly flared edge, narrow flat bottom and raised handle (fig. 4: 9);

b) wide open mug with slightly S-shaped body, and flat bottom, which is provided with a handle that joins the rim with the shoulder (fig. 4: 10);

c) mug with low body, the high vertical upper part thinned to the edge, and slightly raised handle (fig. 3: 5);

d) mugs of truncated cone shape, with raised handle, low body, slightly arched walls and the flat bottom (fig. 8: 1, 3);

e) small mug with pronounced S-shaped body and rounded bottom (fig. 7: 7).

Cups (unornamented) are characterized by the rounded body, the truncated cone shaped neck, and the narrow bottom with an umbo (fig. 7: 10).

Common ware. There are tulip-shaped vessels, jar-shaped pots, and vessels with the bodies of slightly double truncated conical shape.

The tulip-shaped vessels include several variants that differ from each other in morphological characteristics, ornamental motifs, their location on the body, as well as in size and proportions:

a) medium-sized containers with the thin edge, having horizontally arranged oval protrusions below the rim (fig. 3: 8);

b) medium-sized vessels with straight cut or rounded edge, some of which are ornamented with: a row of holes arranged beneath the rim; oval protrusions arranged obliquely on the shoulder of the vessel (fig. 7: 11); a row of holes under the rim in combination with oval protrusions arranged obliquely on the shoulder of the vessel (fig. 8: 12); oval protrusions horizontally arranged on the shoulder of the vessel (fig. 7: 12); a simple belt on the shoulder of the vessel (fig. 8: 11 others are not ornamented (fig. 7: 9); c) vessels with the high trumpet-shaped neck and the body plump at the middle, ornamented with a row of holes arranged below the edge, and below, on the neck, with a horizontal belt of alveoli, from which a similar segment descends (fig. 8: 15).

The jar-shaped pots, with the vertical walls in the upper part, gradually narrowing to the bottom. There are the following variants:

a) large containers with the body slightly widened in the middle, gradually narrowing to the flattened bottom, with the slightly noticible neck and with the horizontal straight edge, which are ornamented below the edge with the massive belt of alveoli interrupted by two symmetrically placed knods (fig. 4: 8);

b) large vessels, with the rim slightly thicker from the outside, ornamented with a row of punctures in combination with an alveolated belt disposed $1.3 \mathrm{~cm}$ below the edge of the vessel (fig. 8: $13)$;

c) vessels slightly rounded pots to the mouth, with the slightly thinned edge bent inward or with the stright vertical edge, one of which is provided below the edge with vertically perforated protrusions (fig. 3: 7; 4: 2).

Vessels of slightly double truncated conical shape. They are of medium and small size, with the slightly flared or vertical edge, ornamented with a row of holes under the edge in association with an alveolated belt placed $2.4 \mathrm{~cm}$ below it (fig. 8: 9); only with a belt $3 \mathrm{~cm}$ below the edge, with alveoli (fig. 4: 7) or simple (fig. 4: 4).

Concluding the presentation of common ware, let us note that in the ornamentation of the bodies of the vessels the belt prevails (with alveoli about $64.7-71.42 \%$ and, respectively, simple ones about 5.88-14.28\%), the share of knobs being only about $14.28-29.4 \%$.

Vessels of double truncated conical shape (amphora-shaped ones) of large size, of the type certified in the habitat complexes from the settlement (fig. 3: 9), are one of the most specific ceramic forms of the Hallstatt era, including the late period, spread over a vast area. The vessels of this type are also represented in the nearby necropolis of Trinca «Drumul Feteştilor» by fragments of thick walls with insufficiently burnished matt outer surface of black color and a smooth inner surface of yellowish-gray (Levițchi 2006, fig. 9: 1, 13).

\section{Wheel-made pottery.}

The wheel-made pottery in Excavations IV and $\mathrm{V}$, in general, was found in conditions similar to those in which hand-shaped pottery was recovered, their shares, as already mentioned, were respectively 8.88 and $4.79 \%$.

In terms of technology, this category of pottery has been made ob a fine clay body, in most cases containing mica of golden color. The color of the fragments is, in particular, gray with lighter or darker shades, rarely light brown. The surface 
of the vessels was covered with slip, subsequently burnished or neatly smoothed.

The assemblage of wheel-made potteru from the Trinca "Izvorul lui Luca» settlement is not numerous. There are:

- Kruglik-type containers - with the thickened, flared, and horizontally cut edge (fig. 5: 1), the short neck undelimited from the rounded body, and the flat bottom (fig. 5: 9; 9: 9), with a narrow rib at the junction of the neck with the body (fig. 5: 6). The dimensions of these containers are different depending on the thickness of the walls (maximum thickness is $1-1,3 \mathrm{~cm}$ ) (fig. 9: 3 , 6-8);

- mugs with the double truncated conical body and the flared edge, with the raised wide band handle with longitudinal grooves on both sides, the outer one being more accentuated. The transition zone from the neck to the body is marked by a ledge and the most prominent part of the body - by a pronounced rib. The bottom of the mug is slightly concave and profiled, with traces of the support of the potter's wheel (fig. 9: 1);

- vessels with relatively thin walls, which, taking into account the fragment of the gradually flared rim (fig. 4: 2) and the reconstructed middle part of another container (fig. 5: 2), are mugs / cups and, possibly, jugs;

- vessels with high handles (fragment length is $9.7 \mathrm{~cm}$ ) with round section, made of fine gray clay body with mica and fine sifted sand, with the burnished surface (fig. 9: 2);

- containers with flared edge, with grooves on the outside, made of fine clay body with mica in the structure, covered with slip and fine burnished (fig. 9: 4, 5).

Other finds are represented by utensils and tools made of clay, stone, flint, and metal (bronze, iron).

The category of objects made of fired clay includs: miniature vessels, which in terms of morphology repeat the types of ordinary vessels; the spindlewhorls round and discoidal in plan and of double truncated conical shape and, respectivly, lenticular in section (fig. 7: 3, 4); possibly, some of the zoomorphous figureines representing a horse, etc.

Flint tools generally attributed to the late Hallstatt period are represented only by the silex blades for sickles, retouched on the edges and with intensive traces of use - the gloss, found in complexes (fig. 3: 2; 7: 2). Other types of flint tools, attested in a large quantity in the settlement, except for those characteristic of the Paleolithic period, may belong to the pre- and post-Hallstatt horizons.

The stone items are represented by compact gray grinders made of quartz sandstone and pestles made of smooth river pebbles.

The metal objects are represented by the rod of a bronze needle with the head broken in old time (fig. 7: 8), the blade of a straight backed knife, and the triangular iron piece.
The late Hallstatt settlement of Trinca «Izvorul lui Luca» due to its geographical position in the western part of the Northern Moldavian Plateau is located on the southern edge of the Western Podolian group area (Levițchi 1992, p. 121). This is an open settlement located on a naturally bounded portion of land - on a promontory. Its topographic features make access to it somewhat difficult. The area of the promontory inhabited in the late Hallstatt period, at the current stage of investigations, is difficult to establish. We can only say that the remains of the late Hallstatt period are located mainly in the southeastern part of it, accordingly, assuming that the currently forested flat area of the promontory, directly adjacent from the east to the area of location of the complexes of the late Hallstatt period, in ancient times was also populated and, possibly, by the community that owned the promontory during the period under consideration.

In this context, it must be mentioned that the settlements exactly attributed to the Western Podolian group in the western part of the Northern Moldavian Plateau - Berlinti (Guchin 1993, manuscript) and Lipcani «La Rabii» (Leviți et al. 2010 , p. 142 - 150) are also located on the promontories. On the promontories are also located the settlements considered to be of the Western Podolian type in the Middle Dniester basin (Лапушнян и др. 1974 , рис. $1, \S 3,4,6-8,15$ ). The settlements of the Western Podolian group communities from the regions immediately adjacent to the Northern Moldavian Plateau on the north - the current regions of Chernivtsi and Ivano-Frankovsk - were also founded primarily on higher ground (promontories, high banks or rivers of ravines) (Мелюкова 1958, с. 32; Крушельницкая 1990, рис. 1, 152).

The site of Trinca «Izvorul lui Luca» is the only excavated settlement of the late Hallstatt period and, along with the mound burial of Trinca «Drumul Fetestilor», it provides important information on the way of life of the Western Podolian communities that populated the Northern Moldavian Plateau during this period.

Surface dwellings in the habitation layer of the late Hallstatt of the housing Hallstatt later, as seen from the above, were found at a depth of about 0.40 to $0.55 \mathrm{~m}$ from the modern ground surface. The remains are platforms and agglomerations about $0.1-0.15 \mathrm{~m}$ thick consisted of adobe pieces (a part of which is relatively smooth and the other retains the prints of large and small diameter rods that intersect at different angles), pieces of daub from hearths, broken limestone stones, and other remnants of material culture. The configuration of the area occupied by them assumes quasi-quadrilateral shapes of constructions (the sides of about $6.0 \times 8.0 \mathrm{~m}$ and $4 \times$ $4.5 \mathrm{~m}$ ) and orientation, with some deviations, on the east-west axis. No pits of pillars/poles were 
found in any of them, which would suggest their presence in the structure of the dwellings. The heating system, identified in one of the dwellings, is an open hearth. Near the dwellings there are stone platforms and pits, some of the latter there are also within the dwellings.

In the regions around the Northern Moldavian Plateau, in the zone of location of the settlements, systematic researches of the settlements were carried out only in the area of the Western Podolian group in the Middle Dniester basin, where both surface and underground dwellings were discovered (Мелюкова 1958, с. 32-33; Петренко 1989, c. 73 ; Смирнова 2004, с. 425), which is typical for this period also in the Upper Dniester region (Крушельницкая 1990a, с. 148-149), the Transcarpathian region of Ukraine (Крушельницкая 1990 a, c. 158), and the Southern Bug basin (Петренко 1989, с. 72).

The surface dwellings, relatively well preserved, which were found in the settlements of the Western Podolian group at Ivane-Puste and Zalissja, represent the constructions with a wooden framework, which had in the structure of walls the corner pillars covered on both sides with a coat of coarse clay mixed with vegetable debris. They are quadrilateral, oriented on the east-west axis, the sides being $6.3 \times 4.1 \mathrm{~m}$ and $10 \times 12 \mathrm{~m}$ respectively, with the floors covered with clay and trimmed. As heating systems, stoves and open hearths were used (Ганіна 1965, с. 106-107; 1984, с. 69). In the settlement of Neporotovo, the surface construction of a rectangular shape with the sides of $8 \mathrm{~m}$ and $14 \mathrm{~m}$ respectively, oriented northeastsouthwest, also had pillars in the structure of the walls (Крушельницька1998, с. 16, рис. 4). The large surface dwelling in the settlement of Dolinjany, represented by two hearths, 8 pits, and several shapeless recesses, does not attest the presence of the pits which implies the presence of the pillars in the construction of the walls (Смирнова 2001 , c. 61,70$)$. Thus, the dwellings found in the Trinca settlement, according to parameters such as the rectangular shape, dimensions, orientation on the east-west axis, the types of heating systems, the presence of pits within them, are close to those used by the communities of the Western Podolian group, while at the same time differing from dwellings from Ivane-Puste and Neporotovo by the absence of pillars in the structure of the walls, and from the first ones also by the absence of clay-coated floors.

The ring of stone along with the platform of flat stones and the large pit (no. 2) located in the southwestern part of its inner area may be the remains of the foundation of an auxiliary construction, of a hut type, built to cover / ptotect the platform and the pit storage. Its walls and roof were made mostly of wood (thin rods, branches) and reed / cane, without subsequent coating with clay, or it was so thin that its fragments did not preserved. The location of this structure near the dwelling 1 allows to consider that the dwelling, the auxiliary construction, and pits 1 and 4 located between them formed a single housing-household complex, in many respects similar to those characteristic of the previous Hallstatt habitation layers in this settlement (Levițki, Sîrbu 2019, in print).

The housing-household complexes, consisting of a dwelling and several auxiliary facilities (openair hearths, pits for storage, pits for household waste etc.) are also certified in other settlements of that time investigated in the basins of the middle courses of Dniester and Dnieper (Смирнова 1981 , с. $43-44$; Ковпаненко и др. 1989 , с. $14-$ 19; Скорый, Бессонова 1996, с. 222-232; Бессонова, Скорый 2001, с. 44-55; Шрамко 1987 , c. $69-82$ etc.). At the same time, structures similar to the auxiliary construction considered here, both in terms of the circular shape, the elements that form it, and of the arrangement in the sites where the analogies of dwellings of both types are identified are not known to us.

The technological categories, the morphological types, the ornamental compositions, the way and the manner of application of the constitutive elements attested in the assemblage of handshaped pottery are common to the pottery of the Western Podolian / Podolian-Moldavian cultural group in the Middle Dniester region and the Rădăuți Depression in Southern Bucovina (Ганіна 1965, с. 107; 1984, с. 70; Смирнова 1978, c. $31 ; 1981$, c. 50 ; Ignat 2006 , p. 55 ), and to the pottery from the late Hallstatt mound burial of Trinca "Drumul Feteştilor» located about 1.5$2 \mathrm{~km}$ to the northeast of the settlement (Levitchi 2006, p. 71). Similar characteristics are also common to the pottery used in the North Thracian cultural environment of the late Hallstatt period in the area between the Dniester and the Danube (Смирнова 1981, с. 50; Крушельницкая 1990а, c. 143 ; Попович 1993, с. 268; Vasiliev 1980, p. 61; Vulpe 1967, p. 37) as well as in the early Scythian cultural environment in the forest-steppe area on the right bank of the Dnieper (Смирнова 1961, с. 92 ; Шрамко 1987, с. 108-110; Ковпаненко и др. 1989 , с. 50).

The wheel-made gray pottery similar / analogous to that found in the Trinca settlement of the late Hallstatt period is known in the sites of several cultures and cultural groups in the area between the Dniester on the east and the Danube on the west.

In the area of the Western Podolian group in the Middle Dniester region and the Rădăuți Depression, this category of pottery is attested in the settlements of Ivane-Puste (Ганіна 1965, c. $109-115$, рис. 1: 8, 9; 4: 9); Zalissja (Ганіна 1984 , с. 74 , рис. $4: 1,6$ ); Dolinjany (Смирнова 1978 , с. 33 , рис. $5: 5$; 1981 , с. $54-55$, рис. 15 ; 1986 , с. 40 , рис. $2: 13,14 ; 3: 1-6,8-10 ; 5: 1$; 1998 , с. 45 , рис. $7: 5,9,10,12,13 ; 2001$, с. 66 , рис. 5: 3, 4, 10); Neporotovo (Крушельницька 
1998, с. 17, рис. 6:2) and in burial complexes: Tumulus (B) of Novoselka Grymalovskaja (Sulimirski 1936 , p. 82-83, Tab. XV: 6); T. I. of Servatincy (Sulimirski 1936, p. 93-94, Tab. XV: 9); T. of Lisičniki (Смирнова 2004, с. 423, рис. 2: 6); T. I. of Kruglik (Смирнова 1968, с. 15, рис. 2: 8); T. 6 of Cajvana (Ignat 2000, p. 336, fig. 2: 6; 2006, p. 28, 62; Pl. XIV: 4); T. 3 of Šutnivcy (Гуцал и др. 1998, с. 75, fig. 2: 15); Т. 2 and 3 of Teklivka (Гуцал и др. 2003, с. 91, 92, fig. 2: 4); T. 4 of Kolodiivka (Гуцал и др. 2005, с. 119); including Т. 5 from the nearby mound burial of Trinca «Drumul Feteştilor» (Levițchi 2006, p. 32, 88; fig. 27: 7).

Much more unevenly and in varying proportions the wheel-made pottery is present in the late Hallstatt cultural units in the CarpathianDanube region: for the Kuštanovice culture from the Transcarpathian region of Ukraine, it is known in limited quantities and only in some burials (Крушельницька 1974, с. 267; Смирнова, Бернякович 1965 , с. 103 ; т. III: 10; Попович 1990 , c. 161 ; 1993 , c. 285 ; Nemeti 1972 , p. 143 ; Moscalu 1983, p. 175); for the Scythian group in Transylvania (cultural aspect Ciumbrud), with some exceptions, it is practically not attested (Moscalu 1983, p. 159; Иерем 1986, прим. 353); for the Ferigile-Bârseşti group in the area of Southern and Curvature Carpathians, it is known only in some burial complexes (Vulpe 1970, p. 189; Vulpe, Popescu 1972, p. 83, 110-111; Morintz 1959, p. 232, Fig. 1: 1) and only in the Vekerzug culture sites in northeastern Hungary, southeast Slovakia and northwest Romania this category of pottery has a relatively large share (Chochorowski 1985, p. 48-51; Йерем 1986, с. 180, прим. 341; Nemeti 1972 , p. $135-138$; 1982, p. $121-122$, 124; Romsauer 1993, p. 16).

The wheel-made pottery is also known in the sites of the early Scythian culture in the forreststeppe zone east of the Dniester (Петренко 1967, с. 12-13; Ковпаненко и др. 1989, с. 85; Шрамко 1998 , с. 125 ; Бессонова, Скорый 2001, с. 81-82; Шрамко и др. 2004, с. 28).

Other finds from the complexes in late Hallstatt layer or from the excavation layers, as evidenced by their analysis, do not have strictly established chronological limits. Most of them have direct parallels in the complexes of the "Drumul Feteştilor» cemetery in the same locality dated from the period from the middle of the $7^{\text {th }}$ century to the first quarter / middle of the $6^{\text {th }}$ century BC (Levitchi 2006, p. 104), which generally corresponds to a period of development of the Western Podolian / Podolian-Moldavian cultural group in the Middle Dniester Basin, the Rădăuți Depression, and the Northern Moldavian Plateau.

Thus, the finds characteristic of late Hallstatt habitation layer, both from the habitat complexes dated from this period and from the excavation layers, in terms of quantity and assortment, are very limited and little informative about the economic activity, domestic occupations, artistic and religious issues of the community that inhabited the Trinca promontory during this period.

Moreover, they are not even chronological indicators that could facilitate the determination of the time sequence when the late Hallstatt community of Western Podolian type inhabited this landform.

Referring to the morphological types of wheelmade gray pottery from the late Hallstatt layer of the Trinka settlement in order to specify the chronological limits of the settlement's existence in the late Hallstatt period, we intend to mention that Greek pottery import is not attested here. The Kruglik-type vessels and mugs of double truncated conical shape with a raised handle both technologically and morphologically are similar to those attested in the Western Podolian group, where, based on Greek imports and other dated objects, this category of pottery is now dated from the period between the last third or the last quarter of the $7^{\text {th }}$ century and the beginning or the first half of the $6^{\text {th }}$ century BC (Смирнова 1993, c. $111 ; 1999$, c. 50,53 ; Smirnova 1998, c. 29-32), while admitting that some Greek pottery imports date back to the beginning of the $5^{\text {th }}$ century BC (Смирнова 2004, с. 423).

\section{LITERATURE}

Boboc, N., Sârodoev, Gh. 2010. Natura. In: Duca, Gh. (ed.). Republica Moldova. Chişinău: Ediție enciclopedică, p. 8-15.

Chochorowski, I. 1985. Die Vekerzug-Kultur. Charakteristik der Funde. Warszawa; Krakow: PWN.

Guchin, V. 1993. Repertoriul monumentelor arheologice din r-nul Briceni, Republica Moldova. Arhiva Muzeului Național de Istorie a Moldovei. Chişinău.

Ignat, M. 2000. Un nouveau groupe culturel du hallstatt tardif sur le territoire de la Roumanie. Studia Antiqua et Archaeologica, VII, p. 331-344.

Ignat, M. 2006. Necropolele tumulare din zona Rădăuți în cadrul lumiitraco-getice(sec. VII-V A. Ch.). Târgovişte: Cetatea de Scaun.

Istoria... 2010. Istoria Moldovei. Epoca preistorică şi antică. Chişinău: Tipografia Centrală.

Levitchi, O. 1992. La situation culturelle et historique dans l'espace Carpato-Dniestrien a l'epoque du Hallstatt. Symposia Thracologica, 9, p. 119-121.

Levitcchi, O. 2006. Necropola tumulară hallstattiană târzie Trinca "Drumul Feteştilor». Iaşi: Trinitas. Bibliotheca Arhaeologica Moldaviae, III.

Leviți, O., Sîrbu, Gh., Babii, A. 2010. Lipcani «La Rabii» - un nou sit arheologic cu nivel de locuire hallstattian tîrziu în zona Podişului Moldovei de Nord. Revista Arheologică, V, 1, p. 142-150.

Levițki, O., Sîrbu, L. 2019. Trinca «Izvorul lui Luca» - un sit al culturii tracice timpurii din zona Podişului Moldovei de Nord. In: Volum omagial Ion Niculiță (in print).

Morintz, S. 1959. Săpăturile de la Bîrseşti (r. Vrancea, reg. Galați). Materiale şi Cercetări Arheologice, VI, p. $231-235$.

Moscalu, E. 1983. Ceramica traco-getică. Bucureşti: Biblioteca Muzeologică.

Nemeti, I. 1972. Necropola hallstattiană de la Sanislău. Satu Mare. Studii şi comunicări, 2, p. 121-148. 
Nemeti, I. 1982. Das Spätthallstattzeitliche Gräberfeld von Sanislău. Dacia, XXVI, 1-2, p. 115-144.

Romsauer, P. 1993. Nove naslezy Vekerzugskej skupiny z Nitry. Slovenská archeológia, XLI, I, p. 539.

Smirnova, G. 1998. Din nou despre ceramica cenuşie lucrată la roată descoperită în siturile scitice timpurii din zona Nistrului Mijlociu. Studii şi Cercetări de Istorie Veche şi Arheologie, 49, I, p. 23-37.

Sulimirski, T. 1936. Scytowe na zachodniem Podolu. Lwów: Lwowskie Towarzystwo Prehistoryczne.

Vasiliev, V. 1980. Sciții agatîrşi pe teritoriul României. Cluj-Napoca: Dacia.

Vulpe, A. 1967. Necropola hallstattiană de la Ferigile. Bucureşti: ARSR. Monografie arheologică.

Vulpe, A. 1970. Cercetări arheologice şi interpretări istorice privind sec. VII-V î. e. n. în spațiul CarpatoDunărean. Memoria Antiquitatis, II, p. 182-213.

Vulpe, A., Popescu, E. 1972. Contribution à la connaissance des débuts de la culture géto-dacique dans la zone subcarpatique Vilcea-Argeş (La nécropole tumulaire de Tigveni). Dacia, XVI, p. 75-111.

Бессонова, С. С., Скорый, С. А. 2001. Мотронинское городище скифбской эпохи. Киев; Краков: ИА НАНУ

Ганіна, О. Д. 1965. Поселення скіфського часу у селі Іване-Пусте. Археологія, XIX, с. 106-117.

Ганина, О. Д. 1984. Поселення ранньоскіфськой доби поблизу с. Залісся. Археологія 47, с. 68-79.

Гуцал, А. Ф., Гуцал, В. А., Мегей, В. П. 1998. Дослидження курганів скіфрького часу у Середньому Подністров'ї. Археологічні відкриття в Україні 1997-1998 pp., с. 74-75.

Гуцал, А. Ф., Гуцал, В. А., Мегей, В. П., Могилов, О. Д. 2003. Результати досліджень курганів скіфрського часу біля с. Теклівка на Поділлі. Археологічні відкриття в Україні 2001-2002 рр., с. 9092.

Гуцал, А. Ф., Гуцал, В. А., Мегей, В. П., Могилов, О. Д. 2005. Кургани ранньоскіфської доби біля села Колодіївка на середньому Дністрі. Археологічні дослідження в Україні 2003-2004 рр., с. 118-119.

Йерем, Э. 1986. Скифский период в восточной Венгрии. В: Титов, В. С., Эрдели, И. (ред.). Археология Венгрии, конеи II тысячелетия до н. э. - I тысячелетие н. э. Москва: Наука, с. 169-187.

Ковпаненко, Г. Т., Бессонова, С. С., Скорый, С. А. 1989. Палятники скифской эпохи Днепровского-лесостепного Правобережья (Киево-Черкасский регион). Киев: Наукова думка.

Кравчук, Ю. П, Верина, В. Н., Сухов, И. М. 1976. Заповедники и памятники природы Молдавии. Кишинев: Штиинца.

Крушельницька, Л. І. 1974. Стародавне населення Прикарпаття і Волині за доби раннього заліза. В: Черниш, О. П. (ред.). Стародавне населення Прикарпатmя і Волині (доба первіснообщинного ладу). Київ: Наукова думка, с. 228-268.

Крушельницкая, Л. И. 1990а. Группа памятников Среднего Поднестровья. Чернолсская культура. В: Балагури, Э. А., Черныш, О. П. (ред.). Археология Прикарпатья, Вольни и Закарпатья (энеолит, бронза и раннее железо). Киев: Наукова думка, c. $135-140$

Крушельницкая, Л. И. 1990b. Культуры Прикарпатья, Волыни и Закарпатья раннескифского времени. В: Балагури, Э. А., Черныш, О. П. (ред.). Археология Прикарпатья, Вольни и Закарпатья (энеолит, бронза и раннее железо). Киев: Наукова думка, с. 141-157.
Крушельницька, Л. І. 1998. Чорноліська культура Середнього Придністров'я (за матеріалами непоротівськоі групи пал'яток). Львів: Місіонер.

Лапушнян, В. Л., Никулицэ, И. Т., Романовская, М. А. 1974. Палятники раннего железного века. Кишинев: Штиинца. Археологическая карта Молдавии, 4.

Левицкий, О. Г. 1986. Поселение раннего железного века у с. Тринка. Археологические исследования в Молдавии в 1982 г., с. 54-71.

Мелюкова, А. И. 1958. Памятники скифрского времени лесостепного Среднего Поднестровья. $\mathrm{Ma}$ териаль и исследования по археологии СССР, 64, c. 5-102.

Петренко, В. Г. 1967. Правобережье Среднего Приднепровья в V-III вв. до н. э. Москва: Наука. Свод археологических источников, Д 1-4.

Петренко, В. Г. 1989. Локальные группы скифообразной культуры лесостепи Восточной Европы. В: Мелюкова, А. И. (ред.). Степи европейской части СССР в скифо-сарматское вреля. Москва: Наука, c. $67-80$.

Попович, И. И. 1990. Памятники Куштановищкой культуры. В: Балагури, Э. А., Черныш, О. П. (ред.). Археология Прикарпатья, Вольни и Закарпатья (энеолит, бронза и раннее железо). Киев: Наукова думка, с. 157-162.

Попович, I. 1993. Куштановицька група пам'яток. В: Крушельницька, Л. (ред.). Пал'ятки гальштатьского періоду межиріччя Вісли, Дністра і Прип'яті. Київ: Наукова думка, с. 250-286.

Рымбу, Н. Л. 1980. Физическая географбия Молдавской ССР (учебное пособие для студентов географбического фбакультета. Кишинев: КГУ.

Рымбу, Н. Л. 1982. Природно-географбиеское районирование Молдаской ССР. Кишинев: Штиинца.

Скорый, С. А., Бесонова, С. С. 1996. Житлово-господарський комплекс Мотронинського городища. В: Супруненко, О. Б. (ред.). Більске городище в контексті вивчення пал'яток раннього залізного віку Європи. Полтава: Археологія, с. 222-232.

Смирнова, Г. И. 1961. Севериновское городище (по материалам Юго-Подольской экспедиции 19471948, 1953 гг.). Археологический сборник государственного Эрлитажа, с. 88-103.

Смирнова, Г. И. 1968. Раскопки курганов у сел Круглик и Долиняны на Буковин. Археологический сборник государственного Эрлитажа, 10. Ленинград, с. 14-27.

Смирнова, Г. И. 1978. Поселение скифского времени у села Долиняны в Днестровском Правобережье (по материалам раскопок 1972-1973 гг. Аpxeологический сборник государственного Эрлитажа, 19 , с. $29-36$.

Смирнова, Г. И. 1981. Новые данные о поселении у с. Долиняны (по материалам раскопок 19771978 гг.). Археологический сборник государственного Эрлитажа, 22, с. 40-61.

Смирнова, Г. И. 1986. Скифоское поселение у с. Долиняны (раскоп "у тока»). В: Смирнова, Г. И. (ред.). Древние палятники культуры на территории СССР. Ленинград: Государственный Эрмитаж, c. $37-42$.

Смирнова, Г. И. 1993. Памятники Среднего Поднестровья в хронологической схеме раннескифрской культуры. Российская археология, 2, с. 101-118.

Смирнова, Г. И. 1998. О работах на раннескифрком поселении у с. Долиняны в 1985 и 1987 гг. Apxeологический сборник государственного Эрлитажа, 33, c. $33-48$. 
Смирнова, Г. И. 1999. Еще раз о серой кружальной керамике из раннескифских памятников Среднего Поднестровья. Археологический сборник государственного Эрлитажа, 34, с. 44-57.

Смирнова, Г. И. 2001. Заключительный сезон работ на раннескифскком поселении у с. Долиняны. Археологический сборник государственного Эрлитажа, 35, с. 59-73.

Смирнова, Г. И. 2004. Состояние изучения Западно-Подольской группы памятников раннескифского времени в Лесостепной Скифии в конце XX века. In: Chochorovski, J. (ed.). Kimmerowie, Scytowie, Sarmaci. Ksiega poswięcona pamięci profesora Tadeusza Sulimirskiego. Krakow, c. 405-429.

Смирнова, Г. И., Бернякович, К. Ф. 1965. Происхождение и хронология памятников Куштановицкого типа Закарпатья. Археологический сборник государственного Эрлитажа, 7, с. 89-115.

Сухов, И. М. 1972. О выделении комплекса геологических и палеонтологических памятников «Припрутские толтры» в Северо-Западной Молдавии. Охрана природы Молдавии, 9, с. 12-19.

Шрамко, Б. А. 1987. Бельское городище скифбской эпохи (город Гелон). Киев: Наукова думка.

Шрамко, Б. А. 1998. Люботинское городище. В: Буйнов, Ю. В. (ред.). Люботинское городище. Харьков: Регион-информ, с. 9-131.

Шрамко, Б. А., Задников, С. А., Зоря, А. О. 2004. Селище скифрского времени у с. Червоносово. Древности 2004, с. 27-32.

Янакевич, А. Н. 1973. Тортонские рифо Молдавии и их охрана. Охрана природь Молдавии, 11, c. $20-31$.

\section{REFERENCES}

Boboc, N., Sârodoev, Gh. 2010. Natura. In: Duca, Gh. (ed.). Republica Moldova. Chişinău: Ediție enciclopedică, p. 8-15.

Chochorowski, I. 1985. Die Vekerzug-Kultur. Charakteristik der Funde. Warszawa; Krakow: PWN.

Guchin, V. 1993. Repertoriul monumentelor arheologice din r-nul Briceni, Republica Moldova. Arhiva Muzeului Național de Istorie a Moldovei. Chişinău.

Ignat, M. 2000. Un nouveau groupe culturel du hallstatt tardif sur le territoire de la Roumanie. Studia Antiqua et Archaeologica, VII, p. 331-344.

Ignat, M. 2006. Necropolele tumulare din zona Rădăuti în cadrul lumii traco-getice (sec. VII-VA. Ch.). Târgovişte: Cetatea de Scaun.

Istoria... 2010. Istoria Moldovei. Epoca preistorică si antică. Chişinău: Tipografia Centrală.

Levitchi, O. 1992. La situation culturelle et historique dans l'espace Carpato-Dniestrien a l'epoque du Hallstatt. Symposia Thracologica, 9, p. 119-121.

Levitchi, O. 2006. Necropola tumulară hallstattiană târzie Trinca "Drumul Feteştilor». Iaşi: Trinitas. Bibliotheca Arhaeologica Moldaviae, III.

Levitki, O., Sîrbu, Gh., Babii, A. 2010. Lipcani «La Rabii» - un nou sit arheologic cu nivel de locuire hallstattian tîrziu în zona Podişului Moldovei de Nord. Revista Arheologică, V, 1, p. 142-150

Levițki, O., Sîrbu, L. 2019. Trinca «Izvorul lui Luca» — un sit al culturii tracice timpurii din zona Podişului Moldovei de Nord. In: Volum omagial Ion Niculiță (in print).

Morintz, S. 1959. Săpăturile de la Bîrseşti (r. Vrancea, reg. Galati). Materiale și Cercetări Arheologice, VI, p. 231235.

Moscalu, E. 1983. Ceramica traco-getică. Bucureşti: Biblioteca Muzeologică.

Nemeti, I. 1972. Necropola hallstattiană de la Sanislău. Satu Mare. Studii şi comunicări, 2, p. 121-148.

Nemeti, I. 1982. Das Spätthallstattzeitliche Gräberfeld von Sanislău. Dacia, XXVI, 1-2, p. 115-144.
Romsauer, P. 1993. Nove naslezy Vekerzugskej skupiny z Nitry. Slovenská archeológia, XLI, I, p. 5-39.

Smirnova, G. 1998. Din nou despre ceramica cenusie lucrată la roată descoperită în siturile scitice timpurii din zona Nistrului Mijlociu. Studii şi Cercetări de Istorie Veche şi Arheologie, 49, I, p. 23-37.

Sulimirski, T. 1936. Scytowe na zachodniem Podolu. Lwów: Lwowskie Towarzystwo Prehistoryczne.

Vasiliev, V. 1980. Scitii agatîrşi pe teritoriul României. Cluj-Napoca: Dacia.

Vulpe, A. 1967. Necropola hallstattiană de la Ferigile. București: ARSR. Monografie arheologică.

Vulpe, A. 1970. Cercetări arheologice şi interpretări istorice privind sec. VII-V î. e. n. în spatiul Carpato-Dunărean. Memoria Antiquitatis, II, p. 182-213.

Vulpe, A., Popescu, E. 1972. Contribution à la connaissance des débuts de la culture géto-dacique dans la zone subcarpatique Vilcea-Argeş (La nécropole tumulaire de Tigveni). Dacia, XVI, p. 75-111.

Bessonova, S. S., Skoryi, S. A. 2001. Motroninskoe gorodishche skifskoi epokhi. Kiev; Krakov: IA NANU.

Ganina, O. D. 1965. Poselennia skifskogo chasu u seli Ivane-Puste. Arkheologiia, XIX, s. 106-117.

Ganina, O. D. 1984. Poselennia rannoskifskogoi dobi poblizu s. Zalissia. Arkheologiia, 47, s. 68-79.

Gutsal, A. F., Gutsal, V. A., Megei, V. P. 1998. Doslidzhennia kurganiv skifskogo chasu u Serednomu Podnistrovi. Arkheologichni vidkrittia v Ukraini 1997-1998 rr. s. 74-75.

Gutsal, A. F., Gutsal, V. A., Megei, V. P., Mogilov, O. D. 2003. Rezultati doslidzhen kurganiv skifskogo chasu bilia s. Teklivka na Podilli. Arkheologichni vidkrittia v Ukraini 2001-2002 rr., s. 90-92.

Gutsal, A. F., Gutsal, V. A., Megei, V. P., Mogilov, O. D. 2005. Kurgani rannioskifskoi dobi bilia sela Kolodiivka na serednomu Dnistri. Arkheologichni doslidyhennia v Ukraini 2003-2004 rr., s. 118-119.

Ierem, E. 1986. Skifskii period v vostochnoi Vengrii. In: Titov, V. S., Erdeli, I. (eds.). Arkheologiia Vengrii, konets II tysiacheletiia do n. e. - tysiacheletie n. e. Moskva: Nauka, s. $169-187$

Kovpanenko, G. T., Bessonova, S. S., Skoryi, S. A. 1989. Pamiatniki skifskoi epokhi Dneprovskogo-lesostepnogo Pravoberezhia (Kievo-Cherkasskii region). Kiev: Naukova dumka.

Kravchuk, Iu. P., Verina, V. N., Sukhov, I. M. 1976. Zapovedniki i pamiatniki prirody Moldavii. Kishinev: Shtiintsa.

Krushelnitska, L. I. 1974. Starodavne naselennia Prikarpattia i Volini za dobi rannogo zaliza. In: Chernish, O. P. (ed.). Starodavne naselennia Prikarpattia $i$ Volini (doba pervisnoobshchnnogo ladu). Kyiv: Naukova dumka, s. 228-268.

Krushelnitskaia, L. I. 1990a. Gruppa pamiatnikov Srednego Podnestrovia. Chernolesskaia kultura. In: Balaguri, E. A., Chernysh, O. P. (eds.). Arkheologiia prikarpatia, Volyni $i$ Zakarpatia (eneolit, bronza i rannee zhelezo). Kiev: Naukova dumka, s. 135-140.

Krushelnitskaia, L. I. 1990b. Kultury Prikarpatia, Volyn i Zakarpatia ranneskifskogo vremeni. In: Balaguri, E. A., Chernysh, O. P. (eds.). Arkheologiia prikarpatia, Volyni $i$ Zakarpatia (eneolit, bronza i rannee zhelezo). Kiev: Naukova dumka, s. 141-157.

Krushelnitska, L. I. 1998. Chornoliska kultura Serednogo Pridnistrovia (za materialami neporotivskoi grupi pamiatok). Lviv: Misionir.

Lapushnian, V. L., Niculitse, I. T., Romanovskaia, M. A 1974. Pamiatniki rannego zheleznogo veka. Kishinev: Shtiintsa. Arkheologicheskaia karta Moldavii, 4.

Levitskii, O. G. 1986. Poselenie rannego zheleznogo veka u s. Trinka. Arkheologicheskie Issledovaniia v Moldove $v$ 1982 g., s. 54-71.

Meliukova, A. I. 1958. Pamiatniki skifskogo vremeni lesostepnogo Srednego Podnestrovia. Materialy $i$ issledovaniia po arkheologii SSSR, 64, s. 5-102.

Petrenko, V. G. 1967. Pravoberezhe Srednego Pridneprovia $v$ V-III vv. do n. e. Moskva: Nauka. Svod arkheologicheskikh istochnikov, D 1-4.

Petrenko, V. G. 1989. Lokalnye gruppy skifoobraznoi kultury lesostepi Vostochnoi Evropy. In: Meliukova, A. I. (ed.). Stepi europeiskoi chasti SSSR v skifo-sarmatskoe vremia. Moskva: Nauka, s. 67-80. 
Popovich, I. I. 1990. Pamiatniki Kushtanovitskoi kultury. In: Balaguri, E. A., Chernysh, O. P. (eds.). Arkheologiia Prikarpatia, Volyni i Zakarpatia (eneolit, bronza i zhelezo). Kiev: Naukova dumka, 157-162.

Popovich, I. 1993. Kushtanovitska grupa pamiatok. In: Krushelnitska, L. (ed.). Pamiatki galshtatskogo periodu mezhrichchia Visli, Dnistra i Pripiati. Kyiv: Naukova dumka, s. 250-286.

Rymbu, N. L. 1980. Fizicheskaia geografiia Moldavskoi SSR (uchebnoe posobie dlea studentov geograficheskoe fakulteta). Kishinev: KGU.

Rymbu, N. L. 1982. Prirodno-geograficheskoe raionirovanie Moldavskoi SSR. Kishinev: Shtiintsa.

Skoryi, S. A., Besonova, S. S. 1996. Zhitlovo-gospodarskii kompleks Motroninskogo gorodishcha. In: Suprunenko, O. B. (ed.). Bilske gorodishche $v$ konteksti vivchennia pamiatok rannogo zaliznogo viku Evropi. Poltava: Arkheolohiia, s. 222232 .

Smirnova, G. I. 1961, Severinovskoe gorodishche (po materialam Iugo-Podolskoi ekspeditsii 1947-1948, 1953 gg.) Arkheologicheskii sbornik gosudrastvennogo Ermitazha, 2, s. $88-103$.

Smirnova, G. I. 1968. Raskopki kurganov u sel Kruglik i Dolineany na Bukovin. Arkheologicheskii sbornik gosudrastvennogo Ermitazha, 10, s. 14-27.

Smirnova, G. I. 1978. Poselenie skifskogo vremeni u sela Doliniany v Dnestrovskom Pravoberezhe (po materialam raskopok 1972-1973 gg.). Arkheologicheskii sbornik gosudrastvennogo Ermitazha, 19, s. 29-36.

Smirnova, G. I. 1981. Novye dannye o poselenii u s. Doliniany (po materialam raskopok 1977-1978 gg.). Arkheologicheskii sbornik gosudrastvennogo Ermitazha, 22, s. 40-61.

Smirnova, G. I. 1986. Skifskoe poselenie u s. Doliniany (raskop u «u toka»). In: Smirnova, G. I. (ed.). Drevnie pamiatniki kultury na territorii SSSR. Leningrad: Gosudrastvenyi Ermitazh, s. 37-42.

Smirnova, G. I. 1993. Pamiatniki Srednego Podnestrovia v khornologicheskoi skheme ranneskifskoi kultury. Rosiiskaia arkheologiia, 2, s. 101-118.

Smirnova, G. I. 1998. O rabotakh na ranneskifskom poselenii u s. Doliniany v 1985 i 1987 gg. Arkheologicheskii sbornik gosudrastvennogo Ermitazha, 33, s. 33-48.

Smirnova, G. I. 1999. Eshche raz o seroi kruzhalnoi keramike iz ranneskifskikh pamiatnikov Srednego Podnestrovia. Arkheologicheskii sbornik gosudrastvennogo Ermitazha, 34 , s. $44-57$

Smirnova, G. I. 2001. Zakliuchitelnyi sezon rabot na ranneskifskom poselenii u s. Doliniany. Arkheologicheskii sbornik gosudrastvennogo Ermitazha, 35, s. 59-73.

Smirnova, G. I. 2004. Sostoianie izucheniia ZapadnoPodolskoi gruppy pamiatnikov ranneskifskogo vremeni v Lesostepnoi Skifii v kontse XX veka. In: Chochorovski, J. (ed.). Kimmerowie, Scytowie, Sarmaci. Księga poswięcona pamięci profesora Tadeusza Sulimirskiego. Krakow, s. 405-429.

Smirnova, G. I., Berniakovich, K. F. 1965. Proiskhozhdenie i khronologiia pamiatnikov Kustanovitskogo tipa Zakarpatia. Arkheologicheskii sbornik gosudrastvennogo Ermitazha, 7, s. $89-115$.

Sukhov, I. M. 1972. O vydelenii kompleksa geologicheskikh i paleontologicheskikh pamiatnikov "Priprutskie toltry» v Severo-Zapadnoi Moldavii. Okhrana prirody Moldavii, 9, s. $12-19$.

Shramko, B. A. 1987. Belskoe gorodishche skifskoi epokhi (gorod Gelon). Kiev: Naukova dumka.

Sramko, B. A. 1998. Liubotinskoe gorodishche. In: Buinov, Iu. V. (ed.). Liubotinskoe gorodishche. Kharkov: ?Region-inform, s. 9-131.

Shramko, B. A., Zadnikov, S. A., Zoria, A. O. 2004. Selishche skifskogo vremeni u s. Chervonosovo. Drevnosti 2004, s. 27-32.

Ianakevich, A. N. 1973. Tortonskie rify Moldavii i ikh okhrana. Okhrana prirody Moldavii, 11, s. 20-31.

\section{О. Г. Левищький, Л. В. Сирбу, Г. В. Сирбу}

\section{КУЛЬТУРНИЙ ШАР ПЕРІОДУ ПІЗНЬОГО ХАЛЬШТАТТУ НА ПОСЕ- ЛЕННІ ТРІНКА ІЗВОРУЛ ЛУЙ ЛУКА (Північно-Молдавське плато)}

Поселення Трінка знаходиться в північно-західній частині Республіки Молдова, на лівому березі річки Прут. Ця територія була більш чи менш заселена як землеробами, так і скотарями, про що свідчать житлові шари поселення Трінка Ізворул луй лука. Пам'ятка розташована приблизно за 2,5 км на південь від південно-західної околиці села Трінка, Сдинецького р-ну.

Пам'ятка Трінка Ізворул луй лука - археологічний об'єкт з кількома культурно-хронологічними горизонтами, включаючи пізньохальштатський період. Поселення цього періоду входить до західноподільської/подільсько-молдавської культурної групи і $е$ единим, дослідженим на Північно-Молдавському нагір'ї. Дослідженнями виявлено ряд комплексів (житло, допоміжні споруди, майданчики, вогнища, ями), артефакти з різної сировини (глина, пісок, камінь, кістка, метал - бронза і залізо), значну кількість інших археологічних залишків (кераміка, остеологічний матеріал, каміння, фррагменти обпаленої глини тощо). Детальний і загальний аналіз всіх елементів, характерних для матеріальної культури, дає нову інформацію про спосіб життя, архітектоніку житла тощо. Все це відіграє дуже важливу роль у дослідженні культурно-історичних процесів періоду пізнього хальштатту в Східно-Карпатському регіоні загалом і на Північно-Молдавському плато зокрема. Результати, безперечно, ще раз підтверджують, що цей край був зоною культурного контакту між пізніми хальштатськими спільнотами (фракійською) в Карпато-Дністровському регіоні та одночасними спільнотами лісостепу на правому березі Дніпра.

Ключові слова: поселення, Трінка «Ізворул луй Лука", Північно-Молдавське Плато, західноподільська / подоло-молдавська група, ранньоскіфрський період, фрракійці, скіфи.

Одержано 08.03.2019

ЛЕВИЦЬКИЙ Олег Георгієвич, доктор істричних наук, Центр археології, Інститут культурної спадщини, б. Щтефран чел Маре, 1, Кішинеу, МД2001, Республіка Молдова, levitkioleg_ipc@yahoo.com.

LEVIȚKI Oleg, doctor habilitat, Center of Archeology of Institute of Cultural Heritage, bl. Ştefan cel Mare, 1, Chişinău, MD2001, Republic of Moldova, levitkioleg_ipc@yahoo.com.

СИРБУ Геннадій Вікторович, науковий співробітник, Центр археології, Інститут культурної спадщини, б. Щтефран чел Маре, 1, Кішинеу, МД2001, Республіка Молдова, ghena_sirbu2014@gmail.com.

SÎRBU Ghenadie, scientific researcher, Center of Archeology, Institute of Cultural Heritage, bl. Ştefan cel Mare, 1, Chişinău, MD2001, Republic of Moldova, ghena_sirbu2014@gmail.com.

СИРБУ Лівія Володимирівна, науковий співробітник, Центр археології, Інститут культурної спадщини, б. Щтефран чел Маре, 1, Кішинеу, МД2001, Республіка Молдова, livermur@yahoo.com.

SIRBU Livia, scientific researcher, Center of Archeology, Institute of Cultural Heritage, bl. Ştefan cel Mare, 1, Chişinău, MD2001, Republic of Moldova, livermur@ yahoo.com. 